\title{
Will the true causal effect please stand up? - A critique of using fixed-effects regression to estimate the effects of personal contacts on wages
}

\author{
Gerhard Krug \\ University of Erlangen-Nuremberg (FAU), gerhard.krug@fau.de \\ Institute for Employment Research (IAB), Germany, gerhard.krug@iab.de
}

\section{Benjamin Fuchs}

University of Erlangen-Nuremberg (FAU), benjamin.fuchs@fau.de

\begin{abstract}
"(P)ersonal contacts are of paramount importance (...). Better jobs are found through contacts and the best jobs with the highest pay and prestige (...) are most apt to be filled in this way" (Granovetter 1974: 22)

"The results [...] indicate that when we use fixed-effects models to difference out fixed unobserved individual characteristics there is little evidence that using contacts increases wages" (Mouw 2003: 882).

"(T)he widely reported null relationship between informal job searching and wages is shown to be mostly [an] artifact" (McDonald 2015: 299)
\end{abstract}

\section{Abstract}

There is an ongoing controversy about whether the correlation between job finding via personal contacts and wages reflects a causal effect. Critics such as Mouw (2003) argue that controlling for unobserved confounders, preferably by fixed-effects regressions, removes spurious correlations and reveals the actual null effect of personal contacts. More recently, however, McDonald (2015) applied fixed effects regressions and found a significantly positive effect. In this paper, we argue that both the Mouw (2003) and McDonald (2015) results are subject to sample selection. Results are potentially biased because their fixed effects estimators exclude those persons who use only one job search method. We propose difference-in-differences matching as an alternative estimator that does not induce the same sample selection bias. Re-analyzing the data used in Mouw (2003) and McDonald (2015), we find that in both cases, this alternative estimator is unbiased by unobserved confounders as well as by sample selection and gives us a causal null effect, which supports Mouw`s (2003) original argument.

This version: January 9, 2019

Word count:Main Article ca. 7500; Appendix A ca. 1500; Appendix B ca. 1500

\section{Acknowledgements}

We are grateful to Steve McDonald for giving us access to his Stata code and thank Ted Mouw for providing open access to his code. We also thank Fabian Ochsenfeld for providing comments on earlier versions of the manuscript. Any remaining errors are our own. 


\section{Motivation for the replication study}

According to Granovetter, the term personal contacts "implies that there is some individual known personally in some context unrelated to a search for job information, from whom he has found out about his new job" (Granovetter 1995:11). Because personal contacts in an individual's social network represent more trustworthy sources than strangers and are in possession of especially rich information on job vacancies, job-finding via personal contacts is assumed to be associated with better jobs, especially in terms of higher wages, as compared to other more formal job search methods. For several decades, controversy regarding the causal interpretation of this association has been observed in social network research (Montgomery 1992, Mouw 2006, Chen 2011). This controversy is fueled by a variety of contradicting results in the literature. The situation seems confusing to such an extent that even review articles cannot agree on whether the empirical literature more often supports or contradicts the thesis of wage effects. For example, Castilla et al. (2013) concluded that "studies suggest that job seekers who use contacts to search for or to find a job achieve better employment outcomes along a variety of dimensions“. In contrast, Chen (2011: 78) found that regarding "the association between using contacts and job outcomes, more studies report no significant effect or even a negative effect on job outcomes".

In his seminal analysis, Mouw (2003, see also 2006, 2002) noted the importance of longitudinal data analysis, especially of fixed effects regressions for eliminating one of the potential reasons for contradicting results in empirical research. Using cross-sectional data, researchers can compare workers who used personal contacts with those who used formal means to find their jobs, and these individuals can differ from each other for a variety of reasons, not all of which can be observed in conventional survey data. Using longitudinal data, researchers can compare the wages of a single worker when he/she uses contacts with the wages of the same worker when he/she uses formal means (Mouw 2003: 880). This strategy controls for unobserved confounding influences as long as they are constant over time.

Mouw compared the results using both approaches and observed that the regression coefficient transformed from a negative value in the cross-sectional analysis to a positive value in the fixed-effects regression. In both cases, the coefficients were not statistically different from zero; thus, Mouw concluded that personal contacts have no causal effect on wages: "intuition and anecdote aside, we have little empirical evidence showing that contacts 
matter" (Mouw 2003: 891). Mouw also concluded that fixed-effects regressions helped uncover the fact that studies applying cross-sectional data yield spurious results. This statement likely made his paper among the most frequently cited papers in the study of personal contacts and wages, despite only few papers actually followed Mouw`s advice.

However, McDonald (2015) recently reanalyzed the original Mouw (2003) data and surprisingly found a positive wage effect. This result was obtained by performing a fixedeffects regression, including in the analysis an additional wave of observations, which was not available during the time of Mouw's analysis, and considering individuals' side jobs. The author concluded that these "findings challenge conventional wisdom on contact effects" (McDonald 2015: 299). Thus, empirical evidence appears to have come full circle, starting with Granovetter's original findings of positive cross-sectional wage differences and followed by Mouw's (2003) conclusion of null results using longitudinal data, and finally, significant positive causal effects using longitudinal data.

McDonald's (2015) results have the potential to realign theoretical reasoning with empirical results in the field of personal contacts and wages. This potential is particularly important because even more than a decade after Mouw's original analysis, cross-sectional data remain the norm and respective studies often report statistically negative wage effects of personal contacts (Bentolila, Michelacci and Suarez 2010; Chua 2011; Diaz 2012; Franzen and Hangartner 2006; Huang and Western 2011; Pistaferri 1999; Ponzo and Scoppa 2010). Thus, based on the results in McDonald (2015) we might conclude that the negative cross-sectional associations found in the literature are biased by unobserved confounders, and once these are controlled for, the true effect of personal contacts on wages is positive.

In this paper, we argue that fixed effects regressions might not be the best method to account for unobserved confounders in the context of personal contacts and wages. To show this, we conduct a replication of the analyses conducted by both Mouw (2003) and McDonald (2015). Our main argument is that applying fixed-effects regression to investigate the effect of personal contacts on wages leads to unintended restrictions on the analytical sample. These restrictions expand beyond the mere fact that at least two employment spells per individual are necessary for fixed-effects regression, which has already been acknowledged by Mouw (2003). The restrictions also expand beyond the fact that only individuals that successfully find a job can enter the analysis, which has already been addressed by McDonald (2015). We argue that in the analyses conducted by both Mouw (2003) and McDonald (2015), the application of fixed-effects regressions leads to the exclusion of a large group of workers, 
namely those who do not change their method of job-finding during the observation period of the study. We refer to these individuals as method keepers, whereas we refer to those who use different methods as method changers. Because fixed effects regressions only use withinperson changes to estimate regression coefficients, method keepers are essentially omitted from the analysis.

To investigate the consequences of omitting the method keepers, we compare the fixed-effects results with results obtained using a similar method with no such sample restrictions, i.e., the so-called Difference-in-Differences Propensity Score Matching ${ }^{1}$. Using this method to reestimate the causal effect of personal contacts using both Mouw's (2003) and McDonald's (2015) analytical data, we find that the causal effect is smaller and statistically insignificant. We argue that Mouw's (2003) original conclusion of no wage effects remains accurate.

\section{Data and data description}

In this paper, we replicate the analyses ${ }^{2}$ presented in Mouw (2003) and McDonald (2015) by applying a different and, in our view, more adequate way to eliminate unobserved confounders to the same data, i.e., the National Longitudinal Study of Youth 1979 (NLSY79). The NLSY79 data consists of a probability sample of individuals born between 1957 and 1964 who lived in the U.S. in 1979. Among the various types of information, information regarding labor market behavior is included and due to the inclusion of questions regarding job finding methods, this survey is particularly suitable for analyzing the wage effects of social capital. Initially, the survey was conducted yearly, but since 1994, the survey was conducted biennially.

\footnotetext{
${ }^{1}$ Recently, An and Winship (2017) also compared fixed-effects regression and difference-in-differenced matching, but in their otherwise comprehensive paper, this difference between both methods, which is highly important for our analysis, is not addressed.

${ }^{2}$ Both Mouw (2003) and McDonald (2015) are concerned with more than the causal effect of personal contacts on wages, but we focus on these aspects of their respective analyses.
} 
Table 1: Descriptive statistics of the Mouw (2003) sample

\begin{tabular}{|c|c|c|}
\hline & Mean & Standard deviation \\
\hline Log hourly wage & 2.269 & 0.561 \\
\hline Used contact to find job & 0.149 & \\
\hline Did not use contact to find job & 0.851 & \\
\hline Employed search & 0.314 & \\
\hline Unemployed search & 0.422 & \\
\hline Employed non-search & 0.171 & \\
\hline Unemployed non-search & 0.092 & \\
\hline Tenure & 1.779 & 2.599 \\
\hline$(\text { Tenure })^{2}$ & 9.921 & 32.603 \\
\hline Experience & 11.975 & 4.010 \\
\hline$(\text { Experience })^{2}$ & 159.487 & 88.059 \\
\hline 1994 & 0.414 & \\
\hline 1996 & 0.304 & \\
\hline 1998 & 0.283 & \\
\hline Sex (female) & 0.489 & \\
\hline Race (Hispanic) & 0.186 & \\
\hline Race (black) & 0.320 & \\
\hline Race (non-black, non-Hispanic) & 0.494 & \\
\hline Years of education & 12.934 & 2.366 \\
\hline Observations (i.e., jobs) & 7400 & \\
\hline Persons & 3277 & \\
\hline
\end{tabular}

We distinguish between two estimation samples in our analysis. The first is the Mouw (2003) sample, which corresponds to the sample used by Mouw (2003, Table 4) in his fixed-effects analysis. This sample includes survey waves 1994, 1996, and 1998, during which information about job-search methods and relevant control variables was collected. The unit of analysis is individuals who changed their main job at least once between 1994 and 1998. Table 2 shows the descriptive statistics of the respective variables in this sample. This sample contains 7,400 observations $^{3}$ from 3,277 individuals. Among the observations in this sample, only $15 \%$ of the individuals found their job via personal contacts. Furthermore, $31 \%$ of the individuals were

\footnotetext{
${ }^{3}$ The original number in Mouw (2003) is 7409, although as already noted by McDonald (2015: 306), running the code provided by Ted Mouw on his homepage leads to this number and the coefficients are identical to those in the Mouw (2003) paper.
} 
employed and actively searching for a job before they found a new job; $42 \%$ of the individuals were unemployed and actively searching; $17 \%$ of the individuals were employed but did not actively search for a job; and $9 \%$ of the individuals were unemployed nonsearchers. Notably, the multinomial variable is based on two dummy variables, i.e., employed/unemployed and searching/non-searching. However, in the NLSY79, non-searchers were not asked about their job-finding method, which is partially obscured by the combined variable. The peculiar coding is important in the subsequent discussion.

Table 2: Descriptive statistics of the McDonald (2015) sample

\begin{tabular}{|c|c|c|}
\hline & Mean & $\begin{array}{l}\text { Standard } \\
\text { deviation }\end{array}$ \\
\hline Log hourly entry wage & 2.33 & 0.532 \\
\hline Used contact to find the job & 0.211 & \\
\hline Used formal means to find the job & 0.527 & \\
\hline Used non-search to find the job & 0.262 & \\
\hline Not employed when hired & 0.509 & \\
\hline Employed when hired & 0.491 & \\
\hline Experience & 12.124 & 4.427 \\
\hline$(\text { Experience })^{2}$ & 166.596 & 103.442 \\
\hline 1994 & 0.363 & \\
\hline 1996 & 0.220 & \\
\hline 1998 & 0.214 & \\
\hline 2000 & 0.203 & \\
\hline Job number & 1.418 & 0.735 \\
\hline Inverse Mill's ratio & 0.401 & 0.136 \\
\hline Sex (female) & 0.483 & \\
\hline Race (Hispanic) & 0.215 & \\
\hline Race (black) & 0.375 & \\
\hline Race (non-black, non-Hispanic) & 0.409 & \\
\hline Years of education & 12.962 & 2.333 \\
\hline Observations (i.e., jobs) & 13570 & \\
\hline Persons & 4871 & \\
\hline
\end{tabular}

The second estimation sample is the McDonald (2015) sample, which corresponds to the one used by McDonald (2015, Table 1) in his fixed-effects analysis. Table 2 shows the descriptive statistics of the respective variables. Wages are slightly lower in the McDonald (2015) sample, possibly because they include wages from side jobs. Moreover, the share of contact 
users is $21.1 \%$ and thus much higher than in the Mouw (2003) data, among others because of a coding error McDonald (2015) identified and corrected. Instead of distinguishing personal contact users from non-users, McDonald (2015) distinguishes them from those who used formal means (52.7\%) and those who found their jobs without an active job-search (26.2\%). For the latter, the theoretically derived assumption is that they were offered a job via their network (see also McDonald and Elder 2006 for further explorations of non-searchers). Approximately half of the observations were from jobs, in which individuals went from job to job without a break, and the other half experienced a period of unemployment before finding a new job. Because wages are entry wages, tenure is omitted from the control variables. The average job number is 1.4 , indicating that many jobs are the main jobs, although a substantial share is side jobs. Based on our own computation, we found that the sample includes 9,471 main jobs and 4,099 side jobs. The mills ratio is also included as a covariate to control for sample selectivity due to the omission of individuals who did not find a job in the sample.

For several reasons, this sample differs from the Mouw (2003) sample (see McDonald 2015). We focus on the differences that are most important for our replication study (see the Appendix B, Table B5 for the consequences of the various changes for the estimated regression coefficient of personal contacts). First, the McDonald (2015) sample contains the same survey waves as the Mouw (2003) sample but additionally includes the wave of 2000 . Second, the Mouw (2003) sample contains all (main) jobs held at the time of the survey, and tenure was controlled for to account for wage development on the job. In contrast, McDonald (2015) focuses on jobs newly started and, thus, starting wages, eliminating the need to control for tenure. Entry wages are analyzed as a slightly different dependent variable than that used by Mouw (2003). Third, the McDonald (2015) sample also includes individuals' side jobs. The data of each individual contain not only one spell, which is mostly the case with panel data, but as many spells per wave as jobs that were newly started in that wave. Consequently, the number of jobs held by an individual during a given survey wave is included as a control variable. Fourth, Mouw (2003) focused on a dichotomous comparison between jobs found via formal means and those found via contacts but controlled for whether individuals did actively search for a job. In contrast, McDonald (2015) focused on a polychotomous comparison between jobs found via formal means or contacts without any search. While the two choices are inconsequential ${ }^{4}$ for the estimate of the effect of personal contacts on wages, McDonald's

\footnotetext{
4 The choice is inconsequential because in the original data, only those individuals who actively searched for a job were asked about their job-finding method. This fact is partially obscured in Mouw's (2003) choice. A
} 
(2015) version is motivated by the theoretical assumption that non-searchers are unobserved network users. As a result of these changes, the McDonald (2015) sample contains 13,570 observations from 4,871 individuals. ${ }^{5}$

\section{Methods: fixed effects regression and difference-in-differences propensity score matching}

Both Mouw (2003) and McDonald (2015) perform a comparison of an individual's wages in subsequent jobs using fixed-effects regressions to identify the causal effect of personal contacts. We can distinguish among three sources of selectivity that can occur using this analytical design. First, certain individuals might have a difficult time finding re-employment after job loss and thus remain unemployed during the subsequent survey wave. Such individuals are underrepresented. Thus, McDonald included the inverse Mills Ratio, which is a method commonly applied to correct for this type of selectivity, in his analysis. Our reanalysis of McDonald's (2015) data showed that excluding the Mills Ratio does not change the results; thus, the second type of selectivity appears to be negligible. Second, as previously acknowledged by Mouw (2003), a comparison is only possible if an individual holds at least two jobs within the observation period. Therefore, individuals with stable employment are also underrepresented in such an analysis. Thus, Mouw (2003) contrasted the OLS results of all jobs with the results of those individuals who held at least two jobs. Mouw found no substantial differences. Here, we are concerned with a third type of selectivity that is specific to the use of fixed-effects regressions in the present context. We refer to this bias as "method changer bias" because it occurs due the omission of those individuals who use the same jobfinding method for all their jobs. We argue that the fixed-effects estimator applied by Mouw (2003) and McDonald (2015) systematically omits method keepers and is only based on method changers.

Fixed effects regression (Halaby 2004; Brüderl and Ludwig 2015) account not only for observed but also unobserved confounders by focusing on intraindividual change. A statistically significant coefficient in a fixed-effects regression indicates that a within-person change between two points in time in the focal independent variable is associated with a within-person change in the dependent variable. This within-person estimate presents a

further inconsequential change by McDonald (2015) was the inclusion of the inverse Mill's ratio (retained from the Heckman model of sample selection correction).

${ }^{5}$ Please note that after running the Stata code that Steve McDonalds graciously provided the numbers we obtained are higher compared with those reported by McDonald (2015, Table 2), although the coefficients and standard errors are practically identical. 
stronger argument for causality compared with static comparisons between persons with different levels of the focal dependent and independent variables (between variation) by differencing out all unobserved confounders as long as they are constant over the observation period. As a consequence, however, all individuals with no within-person change do not contribute to the coefficient estimate of the variable (see Appendix A for details).

Based on Rosenbaum and Rubins' (1983) propensity score estimator, Heckman Ichimura and Todd (1998) developed a non-parametric difference-in-differences propensity score estimator that has properties similar to those of a fixed-effects regression, especially with regard to controlling for unobserved time-constant heterogeneity. This method has been applied to answer a variety of research questions in sociology, e.g., regarding the effect of fixed-term contracts on health (Gebel and Voßemer 2014), etc. Researchers have also recently proposed combining fixed-effects regressions with propensity score matching (An and Winship 2017). However, we argue that both methods differ in at least one important regard: the proposed method can be applied to provide a causal estimate free of unobserved heterogeneity bias while also including observations with no within-person variance on the focal dependent variable. To the best of our knowledge, this important difference has not been addressed in the methodological literature; therefore, we provide more details on how the fixed-effects and the difference-in-differences propensity score estimator differ in their treatment of method keepers (see Appendix A).

The propensity score difference-in-differences estimator is essentially a weighted difference in means, where the weights are chosen based on propensity score matching. Because this estimator uses before and after differences of the dependent variable, but the independent variables enter as levels, the estimator is not restricted to the group of method changers. Therefore, we claim that this method can be used to investigate the consequences of the analytical restrictions of the fixed-effects estimator in the context of Mouw's (2003) and McDonald's (2015) analysis of the wage effects of personal contacts. Another important difference between the fixed-effects and matching estimator is that the latter is nonparametric and does not impose functional form assumptions or require the normal distribution of the outcome variable. As a consequence, it is not necessary to logarithmize wages. Also, to accurately interpret the empirical results later on, it is important to note that the dependent variable is the wage development between two subsequent jobs. 


\section{Replication of the Mouw (2003) analysis}

\section{Replication and discussion of the original fixed-effects estimates}

First, as shown in Table 3, Model 1 replicates the original fixed-effects estimate from Mouw (2003, Table 4). The coefficient is quite large, indicating a 2.4 percent gain in wages for contact users, although this coefficient is statistically insignificant. As stated at the bottom, the regression uses 7,400 observations from 3,277 individuals. Model 2 restricts the analysis to those 909 individuals who changed their job-finding method between jobs. Notably, the estimate of the coefficient of personal contacts is virtually identical to that in the model containing all available cases. Thus, those who always found their job in the same way (method keepers), be it via personal contacts or otherwise, do not contribute to the withinestimate. In Model 3, we condition the sample to only include the method keepers. The regression results contain no coefficient for personal contacts, which is automatically omitted from the regression.

After excluding the method keepers from the analysis, 2,128 observations remain, and therefore, more than 70 percent of all observations in Mouw's analytical sample do not contribute to the estimated effect, which can be problematic because it implies a reduced precision. This reduction in precision is unfortunately not discernable from the standard output since the number of individuals in Model 1 is not only based on those individuals that contribute to a single estimate. Because of the reduction in the effective sample size, excluding the method keepers can lead to problems in the statistical power. In addition, this omission can induce bias if the sub-group of method keepers differs from the group of method changers in a way that is systematically related to the question of the wage effects of personal contacts. For example, we might suspect that job seekers tend to change their methods if they are either dissatisfied with the outcome or no longer able to use their preferred method effectively. 
Table 3: Regression results using the original Mouw (2003) sample

\begin{tabular}{|c|c|c|c|c|c|c|}
\hline \multicolumn{7}{|c|}{ Dependent variable: log hourly wages } \\
\hline & \multicolumn{3}{|c|}{ Fixed-effects longitudinal } & \multicolumn{3}{|c|}{ OLS cross-sectional } \\
\hline & Full sample & $\begin{array}{l}\text { Method } \\
\text { changers }\end{array}$ & $\begin{array}{l}\text { Method } \\
\text { keepers }\end{array}$ & Full sample & $\begin{array}{l}\text { Method } \\
\text { changers }\end{array}$ & $\begin{array}{l}\text { Method } \\
\text { keepers }\end{array}$ \\
\hline & Model 1 & Model 2 & Model 3 & Model 4 & Model 5 & Model 6 \\
\hline $\begin{array}{l}\text { Used contact } \\
\text { to find the } \\
\text { job }^{\mathrm{a}}\end{array}$ & $\begin{array}{l}0.024 \\
(0.015)\end{array}$ & $\begin{array}{l}0.024 \\
(0.016)\end{array}$ & & $\begin{array}{l}-0.027 \# \\
(0.016)\end{array}$ & $\begin{array}{l}0.010 \\
(0.021)\end{array}$ & $\begin{array}{l}-0.093 * \\
(0.039)\end{array}$ \\
\hline $\begin{array}{l}\text { Unemployed } \\
\text { search }^{\text {b }}\end{array}$ & $\begin{array}{l}-0.075 * * * \\
(0.013)\end{array}$ & $\begin{array}{l}-0.051^{*} \\
(0.023)\end{array}$ & $\begin{array}{l}-0.087 * * * \\
(0.015)\end{array}$ & $\begin{array}{l}-0.100 * * * \\
(0.013)\end{array}$ & $\begin{array}{l}-0.099 * * * \\
(0.023)\end{array}$ & $\begin{array}{l}-0.101 * * * \\
(0.015)\end{array}$ \\
\hline $\begin{array}{l}\text { Employed } \\
\text { non-search }^{\text {b }}\end{array}$ & $\begin{array}{l}0.042 * * \\
(0.016)\end{array}$ & $\begin{array}{l}0.026 \\
(0.036)\end{array}$ & $\begin{array}{l}0.043 * \\
(0.018)\end{array}$ & $\begin{array}{l}0.096 * * * \\
(0.017)\end{array}$ & $\begin{array}{l}0.041 \\
(0.039)\end{array}$ & $\begin{array}{l}0.105 * * * \\
(0.019)\end{array}$ \\
\hline $\begin{array}{l}\text { Unemployed } \\
\text { non-search }^{\mathrm{b}}\end{array}$ & $\begin{array}{l}-0.031 \\
(0.024)\end{array}$ & $\begin{array}{l}0.027 \\
(0.050)\end{array}$ & $\begin{array}{l}-0.050 \# \\
(0.027)\end{array}$ & $\begin{array}{l}-0.093 * * * \\
(0.022)\end{array}$ & $\begin{array}{l}-0.096 * \\
(0.046)\end{array}$ & $\begin{array}{l}-0.093 * * * \\
(0.025)\end{array}$ \\
\hline Tenure & $\begin{array}{l}0.031 * * * \\
(0.006)\end{array}$ & $\begin{array}{l}0.025^{*} \\
(0.010)\end{array}$ & $\begin{array}{l}0.034 * * * \\
(0.007)\end{array}$ & $\begin{array}{l}0.049 * * * \\
(0.006)\end{array}$ & $\begin{array}{l}0.042 * * * \\
(0.012)\end{array}$ & $\begin{array}{l}0.052 * * * \\
(0.007)\end{array}$ \\
\hline$(\text { Tenure })^{2}$ & $\begin{array}{l}-0.001 * * * \\
(0.000)\end{array}$ & $\begin{array}{l}-0.002 * \\
(0.001)\end{array}$ & $\begin{array}{l}-0.001 * * \\
(0.001)\end{array}$ & $\begin{array}{l}-0.003 * * * \\
(0.000)\end{array}$ & $\begin{array}{l}-0.002 * \\
(0.001)\end{array}$ & $\begin{array}{l}-0.003 * * * \\
(0.000)\end{array}$ \\
\hline Experience & $\begin{array}{l}0.037 \\
(0.036)\end{array}$ & $\begin{array}{l}0.163 * \\
(0.066)\end{array}$ & $\begin{array}{l}-0.020 \\
(0.044)\end{array}$ & $\begin{array}{l}-0.014 * \\
(0.006)\end{array}$ & $\begin{array}{l}0.007 \\
(0.012)\end{array}$ & $\begin{array}{l}-0.019 * * \\
(0.007)\end{array}$ \\
\hline$(\text { Experience })^{2}$ & $\begin{array}{l}-0.000 \\
(0.001)\end{array}$ & $\begin{array}{l}-0.004 \\
(0.002)\end{array}$ & $\begin{array}{l}0.001 \\
(0.001)\end{array}$ & $\begin{array}{l}0.002 * * * \\
(0.000)\end{array}$ & $\begin{array}{l}0.001 \\
(0.001)\end{array}$ & $\begin{array}{l}0.002 * * * \\
(0.000)\end{array}$ \\
\hline 1996 & $\begin{array}{l}0.103 * * * \\
(0.016)\end{array}$ & $\begin{array}{l}0.057 * \\
(0.028)\end{array}$ & $\begin{array}{l}0.125 * * * \\
(0.019)\end{array}$ & $\begin{array}{l}0.102 * * * \\
(0.014)\end{array}$ & $\begin{array}{l}0.092 * * \\
(0.027)\end{array}$ & $\begin{array}{l}0.108 * * * \\
(0.017)\end{array}$ \\
\hline 1998 & $\begin{array}{l}0.180 * * * \\
(0.016)\end{array}$ & $\begin{array}{l}0.132 * * * \\
(0.028)\end{array}$ & $\begin{array}{l}0.203 * * * \\
(0.019)\end{array}$ & $\begin{array}{l}0.173 * * * \\
(0.014)\end{array}$ & $\begin{array}{l}0.161 * * * \\
(0.025)\end{array}$ & $\begin{array}{l}0.181 * * * \\
(0.017)\end{array}$ \\
\hline $\begin{array}{l}\text { Sex } \\
\text { (female) }\end{array}$ & & & & $\begin{array}{l}-0.191 * * * \\
(0.011)\end{array}$ & $\begin{array}{l}-0.194 * * * \\
(0.021)\end{array}$ & $\begin{array}{l}-0.188^{* * * *} \\
(0.013)\end{array}$ \\
\hline $\begin{array}{l}\text { Race } \\
\text { (Hispanic) }^{c}\end{array}$ & & & & $\begin{array}{l}0.035^{*} \\
(0.015)\end{array}$ & $\begin{array}{l}-0.003 \\
(0.030)\end{array}$ & $\begin{array}{l}0.048 * * \\
(0.018)\end{array}$ \\
\hline $\begin{array}{l}\text { Race } \\
(\text { black) }\end{array}$ & & & & $\begin{array}{l}-0.099 * * * \\
(0.012)\end{array}$ & $\begin{array}{l}-0.149 * * * \\
(0.022)\end{array}$ & $\begin{array}{l}-0.077 * * * \\
(0.015)\end{array}$ \\
\hline $\begin{array}{l}\text { Years of } \\
\text { Education }\end{array}$ & & & & $0.081 * * *$ & $\begin{array}{l}0.067 * * * \\
(0.005)\end{array}$ & $0.086 * * *$ \\
\hline Constant & $\begin{array}{l}1.746 * * * \\
(0.263)\end{array}$ & $\begin{array}{l}0.782 \# \\
(0.434)\end{array}$ & $\begin{array}{l}2.206 * * * \\
(0.322)\end{array}$ & $\begin{array}{l}1.285 * * * \\
(0.050)\end{array}$ & $\begin{array}{l}1.415 * * * \\
(0.097)\end{array}$ & $\begin{array}{l}1.033 * * * \\
(0.056)\end{array}$ \\
\hline Observations & 7400 & 2128 & 5272 & 7400 & 2128 & 5272 \\
\hline Persons & 3277 & 909 & 2368 & 3277 & 909 & 2368 \\
\hline Contact users & 1106 & 957 & 149 & 1106 & 957 & 149 \\
\hline R-squared & 0.092 & 0.079 & 0.101 & 0.327 & 0.28 & 0.341 \\
\hline $\begin{array}{l}\text { Coefficients; } \\
* * * \text { p }<0.001, * \\
{ }^{\mathrm{a}} \text { Reference cat } \\
{ }^{\mathrm{b}} \text { Reference cat } \\
{ }^{\mathrm{c}} \text { Reference cat }\end{array}$ & $\begin{array}{l}\text { gory is "Did } \\
\text { gory is "Em! }\end{array}$ & $\begin{array}{l}\text { parenthes } \\
.05, \# p<0 \\
\text { ot use cont } \\
\text { yed search }\end{array}$ & ic" & & & \\
\hline
\end{tabular}

Whether this unintended selectivity can actually bias the estimates of the effect of personal contacts is an important question. We hypothesize that this is the case. Consider the results of the cross-sectional OLS regressions shown in Table 3, i.e., Models 4-6. Again, we first report the results of the full sample, followed by the results of the separate regressions using the 
method changers and keepers. The coefficient of personal contacts from the full sample (Model 4) is negative and statistically significant at the 10 percent level. Regarding the results of the method changers (Model 5), we obtain a positive coefficient for personal contacts. The result is surprising because even without controlling for unobserved confounders, in the method changers group, personal contacts are positively associated with wages, which casts severe doubt regarding the interpretation that the change from the negative cross-sectional to the positive longitudinal effects is due to the fixed-effects' ability to control for unobserved confounders. In contrast, the method changers are likely a selective group of workers. This suspicion is further supported by the regression coefficient of the method keepers, which is significantly negative.

Altogether, our re-analysis of the original Mouw (2003) data suggests that even if the fixedeffects estimate eliminates bias due to unobserved confounders, sample selection bias is simultaneously introduced due to the inherent omission of the method keepers.

\section{Alternative estimates based on difference-in-differences matching}

In this section, we present the results of the original Mouw (2003) sample after substituting the fixed-effects regression with difference-in-differences propensity score matching. Similar to the above discussion, we distinguish between the full sample and the two sub-samples of method changers and method keepers. Table B1 in Appendix B documents the logistic regressions used to estimate the respective propensity scores. To estimate the propensity scores, we included the same variables that were included in the fixed-effects analysis. In contrast to the FE regression, we also directly controlled for the time constant variables; thus, these variables were also included. Furthermore, we included the lags of the time variant variables for the reasons described above. ${ }^{6}$

\footnotetext{
${ }^{6}$ Several aspects should be noted. First, the number of cases is lower than that in the FE and OLS regressions discussed above because difference-in-differences matching collapses two waves into one wave to generate the before and after difference between the current and previous wages. However, the respective information is still used in the analysis. For example, if an individual originally had two job episodes, one in 1994 and one in 1998, these episodes are collapsed into one episode, where the dependent variable is the difference between the wages in 1998 and 1994. In addition, the covariates contain information from 1998, whereas the lagged variables contain information from 1994.
} 
Table 4: Matching results using the Mouw (2003) sample

\begin{tabular}{|l|l|l|l|l|l|}
\hline \multicolumn{2}{|l|}{ Dependent variable: difference in hourly wages between current and previous job } \\
\hline & $\begin{array}{l}\text { Personal } \\
\text { contacts }\end{array}$ & $\begin{array}{l}\text { Formal } \\
\text { search }\end{array}$ & $\begin{array}{l}\text { Difference } \\
\text { (Causal } \\
\text { effect) }\end{array}$ & $\begin{array}{l}\text { Standard } \\
\text { error }\end{array}$ & $\begin{array}{l}\text { Observations } \\
\text { (from contact } \\
\text { users) }\end{array}$ \\
\hline Full sample (Model 1) & 1.255 & 0.669 & 0.586 & 0.4253 & $3,022(557)$ \\
\hline Method changers (Model 2) & 1.240 & 0.035 & $1.205 \#$ & 0.6014 & $703(306)$ \\
\hline Method keepers (Model 3) & 0.663 & 0.974 & -0.311 & 0.9630 & $1,631(107)$ \\
\hline \multicolumn{7}{|l|}{ Note: All results are based on radius matching with a caliper of $0.01 ; * * * \mathrm{p}<0.001, * * \mathrm{p}<0.01, * \mathrm{p}<0.05, \# \mathrm{p}<0.10$} \\
\hline
\end{tabular}

The propensity score succeeded in eliminating all differences in the observed covariates as evidenced in Table B2 in Appendix B. In Table 4, the causal effects are reported, and in Figures 1 to 3, a graphic representation of the underlying difference-in-differences estimation is presented. Starting with the full sample (Table 3, Model 1 and Figure 1 respectively), the alternative method leads to a difference-in-differences estimate of 0.586 in the sample that contains both method changers and keepers. Wage gains for those who used personal contacts in their current job were 1.255 dollar per hour, whereas the gains for those who used formal search were only 0.669 . As a result, gains in hourly wages between two subsequent jobs is ca. 0.59 dollars greater for those who found the current job via personal contacts. The estimate is slightly positive but statistically insignificant.

Figure 1: Average comparative wage gain through the use of personal contacts (full sample)

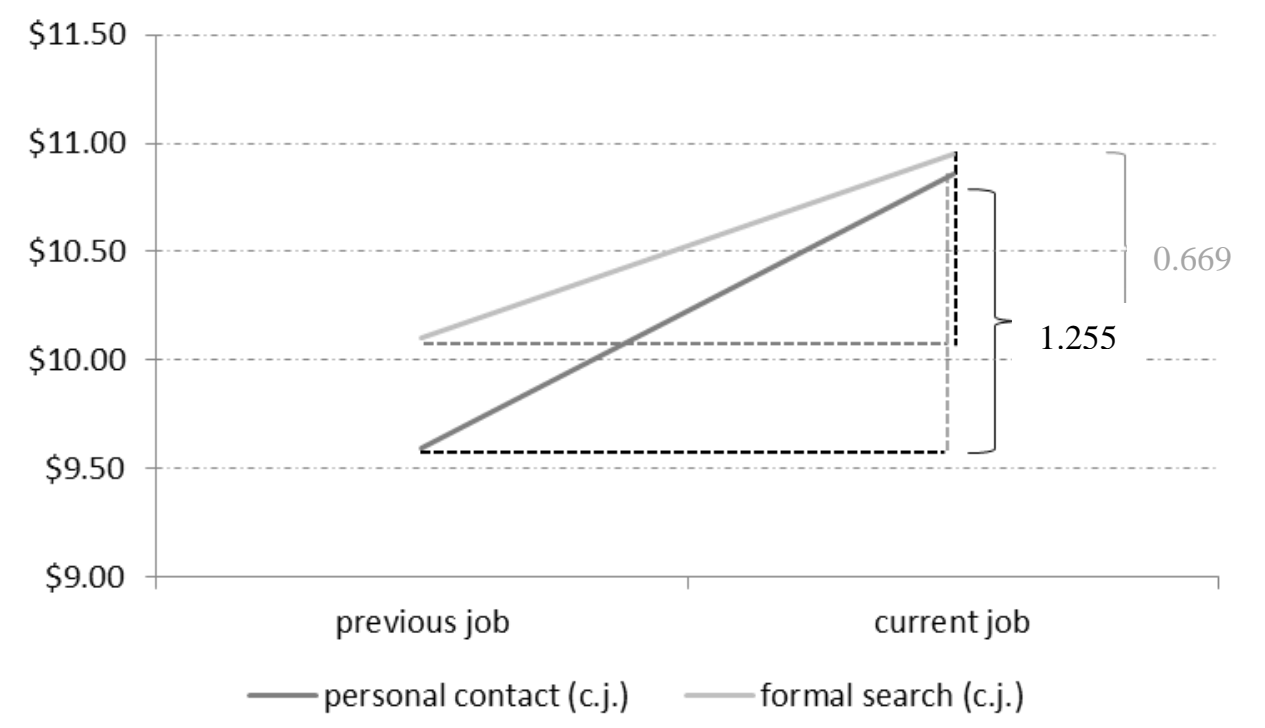

Note: The previous job finding method is independent of the current job (c.j.) finding method 
Models 2 and 3 shown in Table 4 and Figures 2 and 3 provide results from the separate analyses of method changers and method keepers. These analyses reveal that the results of those sub-groups differ substantially and why. In the sub-group of method changers (Model 2), the hourly wage gains are ca. 1.21 dollars higher for those who used personal contacts compared to formal methods. This value is statistically significant. As shown in Figure 2, the divergence between results from the full sample and the method changer sample is mainly due to the different wage development among those who found their current job via formal search, who experienced no wage gains between two jobs.

Figure 2: Average comparative wage gain through the use of personal contacts (method changers)

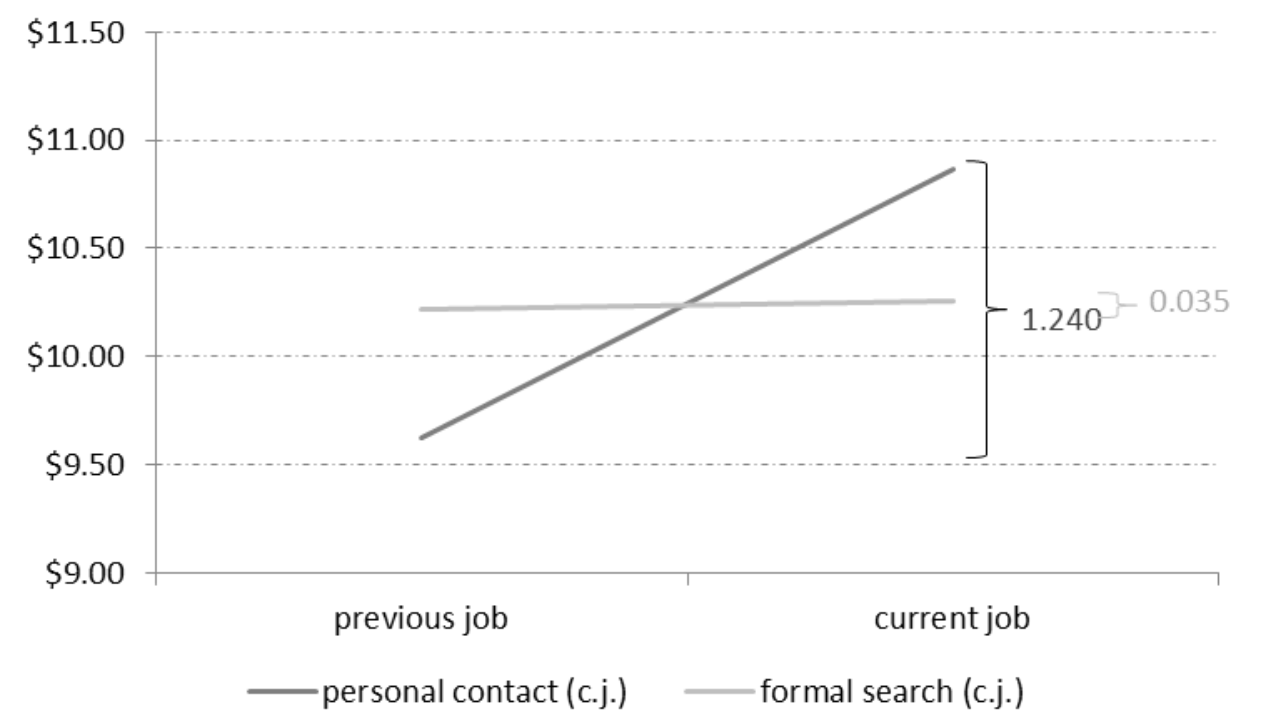

Note: The previous job finding method is different from the current job (c.j.) finding method

In contrast, for the method keepers (Table 4, Model 3), i.e., the sub-group excluded by the fixed-effects estimator, we find an overall negative causal effect because those who used personal contacts to find a job experienced a wage gain that is -0.31 dollars lower compared with those who used formal means to find their job. However, this negative effect is statistically insignificant, which may be because it only relies on slightly more than one hundred contact users. Figure 3 again provides additional graphical information. Both groups experience wage gains, although the gain for those who found their current job via personal contacts is lower. 
Figure 3: Average comparative wage gain through the use of personal contacts (method keepers)

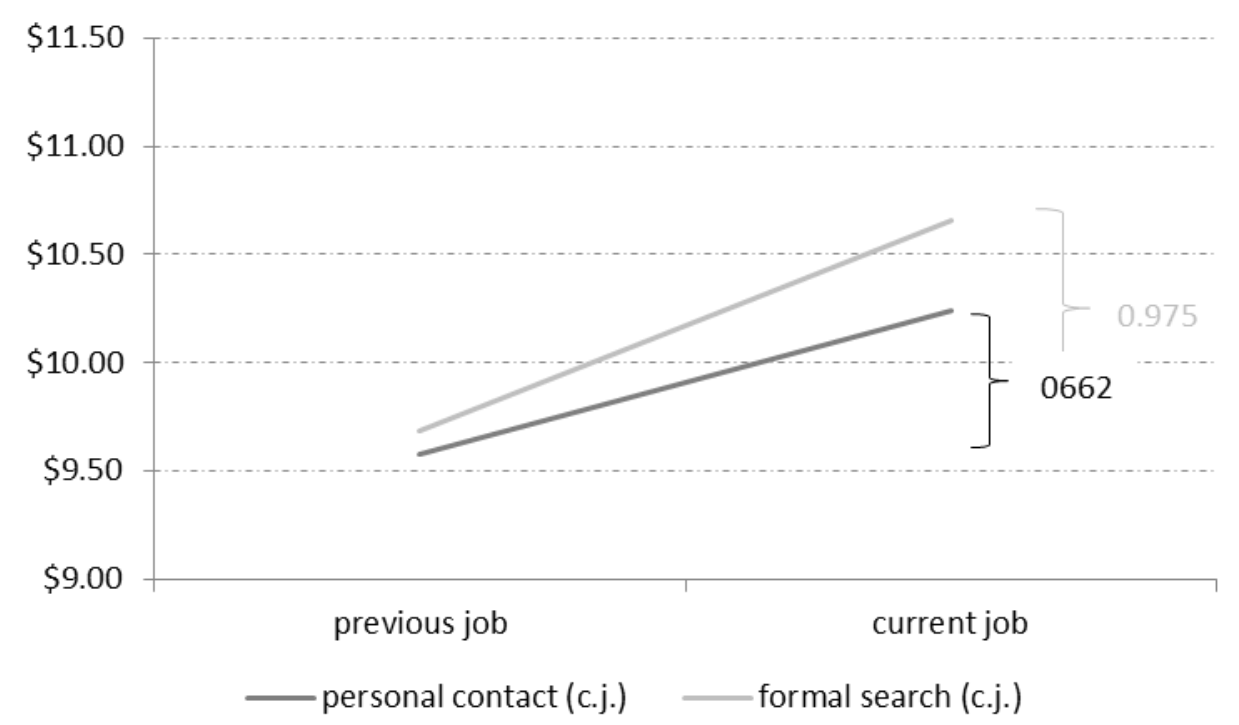

Note: The previous job finding method is identical to the current job (c.j.) finding method

Thus, the replication of Mouw's (2003) analysis with difference-in-differences matching indicated that both groups differ substantially and the signs of the causal effects actually differ between the method keepers and changers. Because of the rather small number of contact users in the NLSY data, both effects do not offset each other. In this data, method keepers are a very small sub-group, and account only for approximately $6 \%$ of all individuals. Therefore, method keepers receive a small relative weight in the overall full sample causal effect estimate and only slightly influence the overall results.

However, with the more prevalent use of personal contacts, the importance of including method keepers increases, which is important to keep in mind in the next section in which the McDonald (2015) analysis is replicated because this analysis increases the number of contact users in the sample.

\section{Replication of the McDonald (2015) analysis}

\section{Replication and discussion of the original fixed-effects estimates}

Unfortunately, when using the McDonald (2015) sample, we cannot conduct an analysis equivalent to that shown in Table 3, in which separate regressions for method keepers and changers are presented in addition to the full sample. The reason is that the McDonald (2015) 
sample differs in how the data were prepared for the analysis ${ }^{7}$ and because different coding was applied to the focal dependent variable. The latter leads to data in which individuals can use the following three different methods: personal contacts, formal means and non-search.

Table 5: Regression results using the extended McDonald (2015) sample

\begin{tabular}{|c|c|c|c|}
\hline \multicolumn{4}{|c|}{ Dependent variable: log hourly entry wages } \\
\hline & $\begin{array}{l}\text { Full sample } \\
\text { FE }\end{array}$ & $\begin{array}{l}\text { Full sample } \\
\text { OLS }\end{array}$ & $\begin{array}{l}\text { Full sample } \\
\text { (person-job) FE }\end{array}$ \\
\hline & Model 1 & Model 2 & Model 3 \\
\hline Used contact to find job ${ }^{\mathrm{a}}$ & $\begin{array}{l}0.019 * \\
(0.009)\end{array}$ & $\begin{array}{l}0.005 \\
(0.009)\end{array}$ & $\begin{array}{l}0.019 \# \\
(0.011)\end{array}$ \\
\hline Non-search ${ }^{\mathrm{a}}$ & $\begin{array}{l}0.023 * \\
(0.010)\end{array}$ & $\begin{array}{l}0.025 \# \\
(0.010)\end{array}$ & $\begin{array}{l}0.026 * \\
(0.011)\end{array}$ \\
\hline Employed when hired & $\begin{array}{l}0.069 * * * \\
(0.008)\end{array}$ & $\begin{array}{l}0.096 * * * \\
(0.008)\end{array}$ & $\begin{array}{l}0.076 * * * \\
(0.010)\end{array}$ \\
\hline Experience & $\begin{array}{l}0.023^{*} \\
(0.009)\end{array}$ & $\begin{array}{l}0.004 \\
(0.003)\end{array}$ & $\begin{array}{l}0.025^{*} \\
(0.010)\end{array}$ \\
\hline$(\text { Experience })^{2}$ & $\begin{array}{l}-0.000 \\
(0.000)\end{array}$ & $\begin{array}{l}0.001 * * * \\
(0.000)\end{array}$ & $\begin{array}{l}-0.000 \\
(0.000)\end{array}$ \\
\hline 1996 & $\begin{array}{l}0.048 * * * \\
(0.011)\end{array}$ & $\begin{array}{l}0.004 \\
(0.010)\end{array}$ & $\begin{array}{l}0.064 * * * \\
(0.012)\end{array}$ \\
\hline 1998 & $\begin{array}{l}0.061 * * * \\
(0.016)\end{array}$ & $\begin{array}{l}0.002 \\
(0.010)\end{array}$ & $\begin{array}{l}0.065 * * * \\
(0.018)\end{array}$ \\
\hline 2000 & $\begin{array}{l}0.122 * * * \\
(0.023)\end{array}$ & $\begin{array}{l}0.035^{* *} \\
(0.011)\end{array}$ & $\begin{array}{l}0.123 * * * \\
(0.026)\end{array}$ \\
\hline Job number & $\begin{array}{l}-0.057 * * * \\
(0.005)\end{array}$ & $\begin{array}{l}-0.072 * * * \\
(0.005)\end{array}$ & \\
\hline Inverse Mill's ratio & $\begin{array}{l}0.740 * * * \\
(0.067)\end{array}$ & $\begin{array}{l}1.434 * * * \\
(0.050)\end{array}$ & $\begin{array}{l}0.698 * * * \\
(0.080)\end{array}$ \\
\hline $\begin{array}{l}\text { Sex } \\
\text { (female) }\end{array}$ & & $\begin{array}{l}-0.053 * * * \\
(0.009)\end{array}$ & \\
\hline $\begin{array}{l}\text { Race } \\
\text { (Hispanic) }^{\mathrm{b}}\end{array}$ & & $\begin{array}{l}-0.129 * * * \\
(0.012)\end{array}$ & \\
\hline $\begin{array}{l}\text { Race } \\
(\text { black })^{b}\end{array}$ & & $\begin{array}{l}-0.209 * * * \\
(0.009)\end{array}$ & \\
\hline Years of education & & $\begin{array}{l}0.022 * * * \\
(0.003)\end{array}$ & \\
\hline Constant & $\begin{array}{l}1.800 * * * \\
(0.078)\end{array}$ & $\begin{array}{l}1.466 * * * \\
(0.032)\end{array}$ & $\begin{array}{l}1.688 * * * \\
(0.083)\end{array}$ \\
\hline Observations & 13570 & 13570 & 13570 \\
\hline Number of caseid & 4871 & 4871 & 8071 \\
\hline Contact users & 2861 & 2861 & 2861 \\
\hline R-squared & 0.103 & 0.347 & 0.116 \\
\hline
\end{tabular}

Coefficients; standard errors in parentheses

$* * * \mathrm{p}<0.001, * * \mathrm{p}<0.01, * \mathrm{p}<0.05, \# \mathrm{p}<0.10$

a Reference category is "Used formal means"

b Reference category is "Non-black, non-Hispanic"

\footnotetext{
${ }^{7}$ Because individuals can simultaneously hold more than one job, there is no longer a clear temporal sequence of jobs.
} 
Therefore, Table 5 (Model 1) simply replicates the results from McDonald's (2015) preferred model. Although the coefficient is similar in size to the original Mouw analysis, the difference is now statistically significant. Using personal contacts on average increases hourly wages by 2 percent. If we estimate an OLS Regression using the full sample (Model 2), the coefficient is not negative relative to that of the Mouw (2003) sample, and the value is close to zero and statistically insignificant. The coefficient of non-search is positive and statistically significant in both the fixed-effects and OLS regressions.

Because individuals can simultaneously hold more than one job, there is no longer a clear temporal sequence of jobs. Therefore, McDonald (2015) computed the averages to de-mean the variables by pooling all jobs held by an individual during the observation period. An alternative that is closer to how we conduct the DID PSM analysis could be to use the personjob as the observed individual (see Table 5, Model 3), i.e., only compare jobs of the same type within the same individual (only main jobs with main jobs and only side jobs with side jobs). Using this approach, unobserved confounders, such as the reservation wage, are allowed to differ for only the main or any of the side jobs. Accounting for this possibility does not substantially change the point estimate, even if the coefficient is only significant at the 10 percent level. Thus, we believe that any differences between the fixed-effects and differencein-differences propensity score matching estimates are not due to this difference in the data processing.

\section{Alternative estimates based on difference-in-differences matching}

In his study investigating network effects across the earning distribution, a large proportion of the analysis conducted by McDonald (2015) is devoted to improving upon Mouw's (2003) original estimate. Several changes are adopted compared with Mouw's (2003) research design; most importantly, more observations are added by including side jobs and changing the coding of the focal dependent variable from a "binary treatment" (personal contacts versus formal means) to a "multiple treatment" (personal contacts versus formal means versus nonsearch). Because of the categorical nature of the focal independent variable, we must estimate two propensity scores, i.e., a score for matching personal contact users to users of formal means and a score for matching non-searchers to users of formal means (Lechner 2001), yielding two respective causal effects.

Re-analyzing the extended McDonald (2015) sample also starts with estimating the propensity scores. Again, for the covariates to be balanced via matching, we include all the covariates 
from the respective regression model augmented by time variables in the logistic regression to estimate the propensity score (see Table B3). In the case of the McDonald (2015) sample, the job number and mills ratio are also included. Again, we also include the lagged variables, except for the job number, the lag of which is identical to the current value. We constructed the dependent variable not only as the difference between the current and previous wage but also restricted the difference between two jobs with the same number. Thus, for main jobs, we only use main jobs, and for side jobs, we only use side jobs ${ }^{8}$. We first estimate the probability of finding a job via contacts versus finding a job via formal means, and then, we estimate the probability of finding a job without searching versus finding a job via formal means (Models 1 and 2 in Table B3). The "multiple treatment" setup in McDonald's analysis is compared to the "binary treatment" setup in Mouw's analysis. Given the structure of the original survey data, distinguishing among personal contacts, formal means and non-search as three distinct alternatives is more logical than controlling for a multinomial variable that combines search and employment status ${ }^{9}$. This logicality is also evidenced by the ability of the logistic regression to provide regression coefficients for all control variables compared with the Mouw (2003) data (see Table B3). Table B4 in Appendix B provides the respective balancing tables.

Table 6: Matching results using the McDonald (2015) sample

\begin{tabular}{|l|l|l|l|l|l|}
\hline Dependent variable: difference in hourly wages between current and previous job \\
\hline & $\begin{array}{l}\text { Personal } \\
\text { contacts }\end{array}$ & Formal search & $\begin{array}{l}\text { Difference } \\
\text { (Causal effect) }\end{array}$ & Standard error & $\begin{array}{l}\text { Observations } \\
\text { (from contact } \\
\text { users })\end{array}$ \\
\hline Full sample (Model 1) & 1.241 & 1.264 & -0.023 & 0.2729 & $4,046(1,120)$ \\
\hline \multicolumn{7}{|c|}{} & Non-search & Formal search & $\begin{array}{l}\text { Difference } \\
\text { (Causal effect) }\end{array}$ & Standard error & $\begin{array}{l}\text { Observations } \\
\text { (from } \\
\text { searchers } \\
\text { users })\end{array}$ \\
\hline & 2.529 & 1.843 & $0.685^{*}$ & 0.2772 & \begin{tabular}{l}
$4,371(1,442)$ \\
\hline
\end{tabular} \\
\hline
\end{tabular}

\footnotetext{
${ }^{8}$ This is performed first because conducting the intraperson comparison wage $e^{\text {cur }}-$ wage $e^{\text {prev }}$ only for the same types of jobs is logical. This procedure slightly differs from that performed originally by McDonald (2015), who treats all wages equally, except for controlling for the job number in the fixed-effects regression. A fixed-effects regression can, in principle, also be conducted to only compare the same types of jobs within the biography of one person, but the results are similar (see Table 5, Models 1 and 3).

${ }^{9}$ Notably, in the case of a regression analysis, the decision has no consequences. The results are virtually identical to those of an analysis of personal contacts using the multiple treatment setup used in Mouw's (2003) analysis (see Appendix B, Table B5).
} 
Similar to Mouw's (2003) analysis, McDonald's estimate is a fixed-effects estimate and, thus, is only based on the method changers. However, as already pointed out above, the coding of the focal independent variable makes it impossible to conduct separate analyses for method changers and keepers. Instead, Table 6 presents the results of our matching analysis, which includes both method keepers and changers when estimating the causal effect. In our replication of Mow's (2003) analysis, we found a positive but insignificant coefficient for personal contacts, and this result is similar to that of the original Mouw analysis. However, the results diverge from McDonald (2015), replicated here in Table 5, at least with respect to personal contacts. Those who found their job via personal contacts experience practically the same wage development between two jobs compared with those who found it via formal means, even if the latter started from a slightly lower level (see Table 6, Model 1 and Figure 4). The difference in hourly wage development is only -0.02 dollars, which is statistically insignificant. This finding contrasts with the results which McDonald (2015) obtained from a fixed-effects regression, where the coefficient was quite large and statistically significant. As a consequence, the difference-in-differences matching estimate is more consistent with the original Mouw (2003) results of no wage effects of personal contacts.

Figure 4: Average comparative wage gain through the use of personal contacts (full sample)

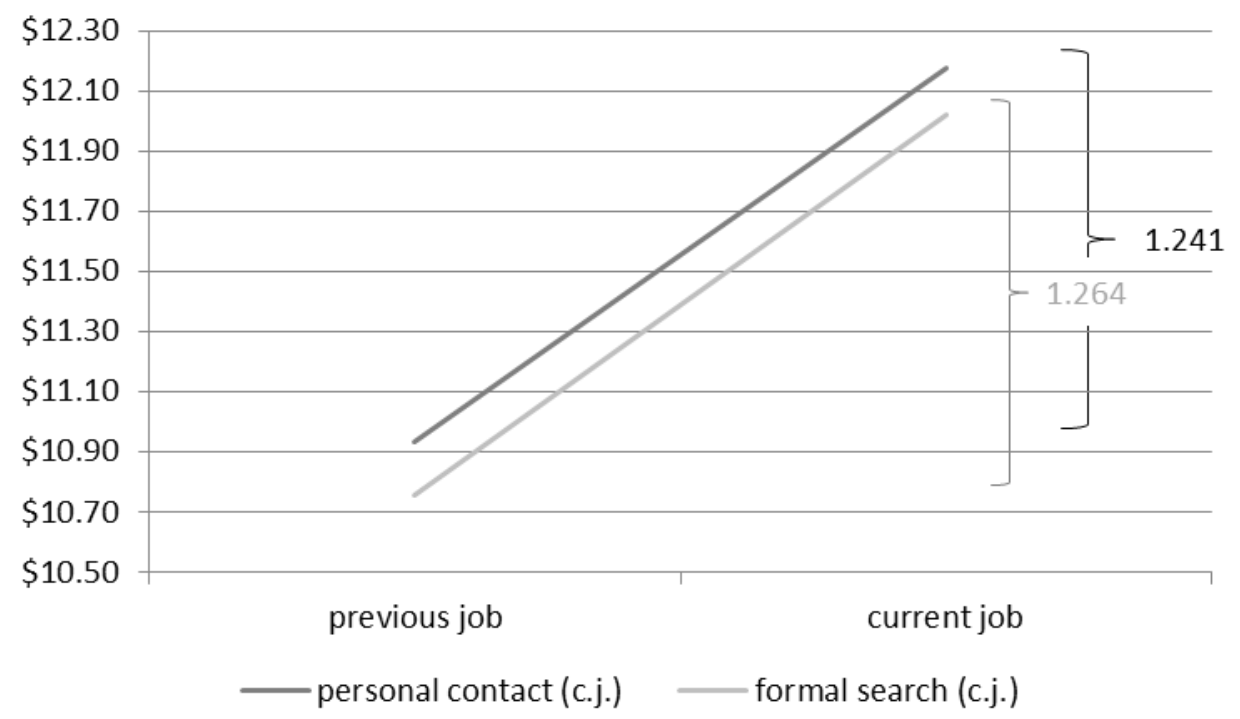

Note: The previous job finding method is different from the current job (c.j.) finding method 
Even if our main focus is on personal contacts and wages, to provide a thorough analysis, we also report our difference-in-differences results for non-searching, too. For the comparison of non-searchers with formal searchers, the difference-in-differences estimate is 0.68 dollars and statistically highly significant (Model 2 of Table 6). Therefore, the matching analysis replicates the fixed-effects results for non-searchers, even if it does not replicate the results for personal contact users. As Figure 5 reveals, non-searchers are in general characterized by a higher wage level than personal contact users. The previous wages of contact users were approximately 10.90 dollar and rose to ca. 12.20 , whereas the previous wages for nonsearchers were already above 12 dollars and rose to above 14.50 after finding a new job.

Figure 5: Average comparative wage gain through non-search (full sample)

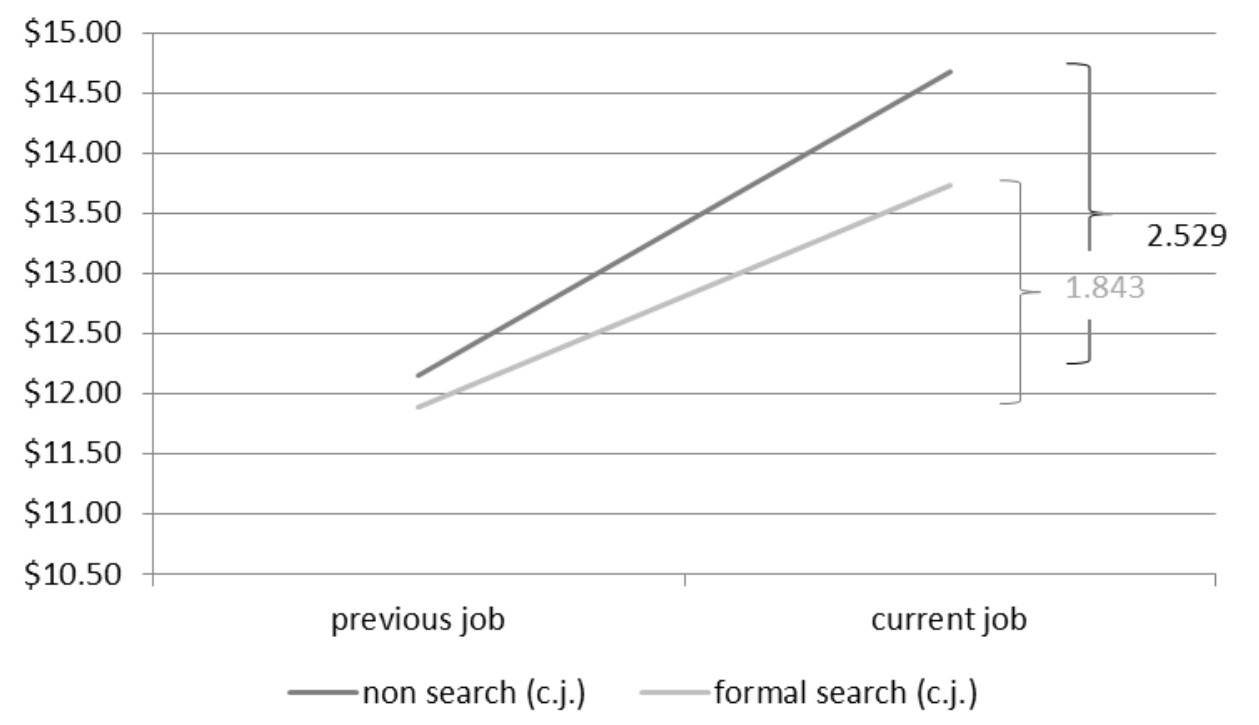

Note: The previous job finding method is different from the current job (c.j.) finding method

\section{Discussion and conclusions}

According to Mouw (2003), controlling for unobserved confounders is important. Failing to do so results in a spurious correlation between personal contacts and wages. However, once the bias due to unobserved confounders is eliminated, using personal contacts to find a job is no longer statistically significantly related to wages. Thus, Mouw (2003) concluded that despite comprehensive theoretical and anecdotal evidence, personal contacts have no positive impact on wages. Recently, McDonald (2015) re-analyzed and extended Mouw's data by also controlling for unobserved heterogeneity and found a positive and statistically significant effect, suggesting that a major part of Mouw's skeptical conclusions might be obsolete. 
In this paper, we have shown that the method used to control for unobserved heterogeneity by both Mouw (2003) and McDonald (2015) is prone to restricting the causal estimate to a selective analytical sample, at least if applied to the question of interest. Removing this restriction in our replication of both Mouw (2003) and McDonald (2015) leads to causal estimates that are consistent with Mouw's original conclusions of null effects for personal contacts, although it contradicts the positive and significant coefficient from McDonald (2015). However, our analysis supports McDonald`s (2015) results of a positive and significant effect of non-searching on wages. Under the assumption that non-searchers are "hidden" contact users, our results indicate that personal contacts only influence wages if they provide individuals with unsolicited job offers. For those who engage contacts themselves, personal contacts have no advantage over formal methods.

Thus, at the very least, our results show that the estimated effect of personal contacts and wages is dependent on the selection between two reasonable and generally similar statistical procedures. However, we argue that in this particular application, the results of the differencein-differences propensity score matching are more trustworthy because this method includes all job-finding sequences rather than only those where changes in the job-finding method occur. Therefore, our results not only reveal that the answer to the wage effects of personal contacts is sensitive to the applied method but also show that in the specific case of regressing wages on job-finding via personal contacts, fixed-effects regression can be problematic and should be avoided or at least interpreted with great care.

Two additional points are important. First, we do not argue that Mouw (2003) or McDonald (2015) were mistaken to apply fixed-effects regressions. To the contrary, we agree that these methods are an important improvement compared with cross-sectional methods. Second, we have no reason to believe that the above-described problems of fixed-effects estimates extend to all applications. For example, An and Winship (2017) compared the results of a fixedeffects regression and difference-in-differenced Mahalanobis distance matching and found no substantial differences. We believe that several circumstances must coincide to elicit the observed bias. First, we performed a comparison of two events (job-finding via contacts versus formal methods) instead of the usual comparison of a base state with the state after an event has occurred (e.g., unmarried versus married) or the change in a continuous variable (e.g., tenure). Second, the type of event that occurs is to a large degree influenced by the observed agent (self-selection); thus, whether the agent selects two identical or different events that follow each other is based on his/her expectations for obtaining a specific outcome (this is not the case in An and Winship 2017, who analyze the race of interviewers). In our 
case, we suspect that agents who were satisfied with the outcome of their job-finding method are likely to use the same job-finding method in the future. In contrast, agents who are dissatisfied will likely attempt to use a different method next time. Third, bias is more likely to occur if one of the two alternatives is very rare. In this case, a large group of individuals exhibit no within-person variance, which could create bias, even in case of random selection, because a small sub-group of all individuals is less likely to represent the total population than a larger sub-group.

Based on the above criteria required for bias to occur, we believe that the problem is specific to the use of the fixed-effects regression combined with measuring the use of networks in job searches via the (binary) indicator "job-finding via personal contacts". Other measures, such as the network size or contact frequency, should be less prone to similar bias because these measures are less likely to fulfill the above criteria. Therefore, researchers interested in the causal effect of networks on wages should focus on network characteristics rather than contact use, a recommendation that has already been made by Montgomery (1992) but for different reasons. 


\section{References}

An, Weihua and Christopher Winship. 2017. "Causal Inference in Panel Data With Application to Estimating Race-of-Interviewer Effects in the General Social Survey." Sociological Methods \& Research 46(1):68-102.

Bentolila, Samuel, Claudio Michelacci and Javier Suarez. 2010. "Social Contacts and Occupational Choice." Economica 77(305): 20-45.

Brüderl, Josef and Volker Ludwig. 2015. "Fixed-Effects Panel Regression." Pp. 327-358 in The Sage Handbook of Regression Analysis and Causal Inference, edited by H. Best and C. Wolf. Los Angeles: Sage Reference.

Caliendo, Marco and Sabine Kopeinig. 2008. "Some Practical Guidance for the Implementation of Propensity Score Matching." Journal of Economic Surveys 22(1):3172.

Castilla, Emilio J., George J. Lan and Ben A. Rissing. 2013a. "Social Networks and Employment: Mechanisms (Part 1)." Sociology Compass 7(12):999-1012.

Castilla, Emilio J., George J. Lan and Ben A. Rissing. 2013b. "Social Networks and Employment: Outcomes (Part 2).” Sociology Compass 7(12):1013-1026.

Chen, Yunsong. 2011. "The Causal Effect of Social Capital in the Labor Market. Identification Challenges and Strategies. "Chinese Sociological Review 44: 76-100.

Chua, Vincent. 2011. "Social networks and labour market outcomes in a meritocracy." Social Networks 33(1):1-11.

Diaz, Ana M. 2012. "Informal Referrals, Employment, and Wages: Seeking Causal Relationships." Labour 26:1-30.

Franzen, Axel and Dominik Hangartner. 2006. "Social networks and labour market outcomes: The non-monetary benefits of social capital." European Sociological Review 22(4):353368.

Gebel, Michael and Jonas Voßemer. 2014. "The impact of employment transitions on health in Germany. A difference-in-differences propensity score matching approach.” Social Science \& Medicine 108:128-136.

Granovetter, Mark. 1995. Getting a Job: A Study of Contacts and Careers. 2nd edition. Chicago: University of Chicago Press.

Granovetter, Mark. 1974. Getting a Job: A Study of Contacts and Careers. 1st edition. Chicago: University of Chicago Press.

Heckman, James J., Hidehiko Ichimura and Petra Todd. 1998. "Matching as an Econometric Evaluation Estimator." Review of Economic Studies 65:261-294.

Huang, Xianbi and Mark Western. 2011. "Social networks and occupational attainment in Australia." Sociology 45(2):269-286.

Lechner, Michael. 2001. "Identification and estimation of causal effects of multiple treatments under the conditional independence assumption." Pp. 43-58 in Econometric Evaluation of Labour Market Policies. ZEW Economic Studies. Vol. 13, edited by M. Lechner and F. Pfeiffer. Heidelberg: Physica.

McDonald, Steve and Glen H. Elder. 2006. "When does social capital matter? Non-searching for jobs across the life course." Social Forces 85(1):521-550.

McDonald, Steve. 2015. "Network effects across the earnings distribution: Payoffs to visible and invisible job finding assistance.” Social Science Research 49:299-313. 
Montgomery, James D. 1992. "Job Search and Network Composition: Implications of the Strength-Of-Weak-Ties Hypothesis.” American Sociological Review 57(5):586-596.

Mouw, Ted. 2006. "Estimating the causal effect of social capital: A review of recent research." Annual Review of Sociology 32:79-102.

Mouw, Ted. 2003. "Social capital and finding a job: do contacts matter?" American Sociological Review 68(6):868-898.

Mouw, Ted. 2002. "Racial differences in the effects of job contacts: Conflicting evidence from cross-sectional and longitudinal data." Social Science Research 31(4):511-538.

Pistaferri, Luigi. 1999. "Informal networks in the Italian labor market." Giornale degli Economisti e Annali di Economia 58(3-4):355-375.

Ponzo, Michela and Vincenzo Scoppa. 2010. "The use of informal networks in Italy: Efficiency or favoritism?" The Journal of Socio-Economics 39(1):89-99.

Rosenbaum, Paul R. and Donald B. Rubin. 1983. "The Central Role of the Propensity Score in Observational Studies for Causal Effects." Biometrika 70(1):41-55.

Schuller, Tom, Stephen Baron and John Field. 2000. "Social capital: A Review and Critique." Pp. 1-38 in Social Capital: Critical Perspectives, edited by S. Baron, J. Field and T. Schuller. Oxford: Oxford University Press.

Smith, Jeffrey A. and Petra E. Todd. 2005. "Does matching overcome LaLondes's critique of nonexperimental estimators?” Journal of Econometrics 125(1-2):305-353. 


\section{Appendix A: Comparing the role of method keepers in fixed-effects regressions and difference- in-differences matching}

In this appendix, we compare fixed-effects regressions and propensity score matching with respect to the treatment of method keepers.

\section{Fixed-effects regressions}

We start with fixed-effects regressions (Brüderl and Ludwig 2015) and point out that the problem in fixed-effects regression arises from the well-known reliance of the estimate on within-variation only; however, this problem is aggravated by the specifics of the subject matter under investigation, i.e., the effect of job-finding via personal contacts on wages. Let us assume that there is a panel survey where $\mathrm{t}=1, \ldots, \mathrm{T}$ denotes the survey waves and $\mathrm{i}=1, \ldots, \mathrm{N}$ denotes the surveyed individuals. The dependent variable is lnhwage $e_{i t}$ for the logarithm of hourly wages, where the subscripts indicate that this variable varies between individuals and within each individual over time. The first step in describing the properties of fixed effects estimates is the error component model, which decomposes the error into two parts. $\epsilon_{i t}$ is random error that varies between individuals and over time, and $\alpha_{i}$ is the systematic error that varies only between individuals but is fixed over time:

lnhwage $_{i t}=\beta_{1}$ sex $_{i}+\beta_{2} p c_{i t}+\alpha_{i}+\varepsilon_{i t}$

The second step is to average all variables over their different values at different time points as indicated by the bar. Because $\alpha_{i}$ is fixed over time, demeaning does not change the fixed error component.

$\overline{\text { lnhwage }}_{i}=\beta_{1} \overline{\operatorname{sex}}_{i}+\beta_{2} \overline{p c}_{i}+\alpha_{i}+\bar{\varepsilon}_{i t}$

We arrive at the second fixed estimator if we 'demean' or 'within transform' the variables in equation (1) with the values in equation (2).

$\operatorname{lnhwage}_{i t}-\overline{\operatorname{lnhwage}}_{i}=\beta_{1}\left(\operatorname{sex}_{i}-\overline{\operatorname{sex}}_{i}\right)+\beta_{2}\left(p c_{i t}-\overline{p c}_{i}\right)+\left(\varepsilon_{i t}-\bar{\varepsilon}_{i t}\right)$

This fixed-effects model has several interesting properties, and certain properties are more desirable than others. Let us assume that sex is constant over time (as indicated by the missing subscript $\mathrm{t}$ ), whereas $p c$ varies over time. First, the within-transformation eliminates the systematic error component. Therefore, even unobserved confounders cannot bias the coefficient estimates if one can reasonably assume that they are fixed over time or at least over the observation period of the panel survey. Second, for variables that are also constant over time, no coefficients can be estimated because $\operatorname{sex}_{i}-\overline{\operatorname{sex}}_{i}$ is zero for all $\mathrm{i}=1, \ldots, \mathrm{N}$. Third, even for variables that change over time, such as pc, which is the job-finding method, not all individuals experience such change during the observation period. In the empirical analysis, we defined the method keepers as those who use the same method to obtain different subsequent jobs. The method keepers do not contribute to the respective coefficient estimate of $\beta_{2}$ because their $p c_{i t}-\overline{p c}_{i}$ value is zero. Thus, the estimate of $\beta_{2}$ is exclusively identified in the sub- 
group of individuals who used different methods, i.e., method changers. ${ }^{10}$ The method keepers, i.e., those who use one job-finding method for all their jobs during the observation period, are automatically excluded, at least for the estimate of $\beta_{2}$. This exclusion is not problematic in general, although it can be under at least two circumstances. First, problems might arise if those who use the same method again differ with respect to the dependent variable from those who change their preferred method during two episodes of the job search. For example, we might assume that method changers are dissatisfied with the outcome of their previous job search, such as with respect to their obtained wages, and this motivates the change in methods. Second, problems can also arise if the focal independent dummy variable is skewed, i.e., there are only few ones and many zeros, which is observed here. In this case, even random differences might lead to method changers being different from method keepers.

\section{Difference-in-differences propensity score matching}

Compared with fixed effects regressions, with difference-in-differences propensity score matching, the problem of omitting method keepers can be circumvented. As we will show below, the main reason is that with the matching estimator, only the outcome variable is differenced, but the independent variables enter the propensity score equation as levels, not differences. As a consequence, method keepers do not drop out of the analysis.

The estimator has the following form, in which we used notations specific to the subject matter of personal contacts and wages (see Smith and Todd 2005 for more general notations and a discussion of the advantages and disadvantages of the estimator) ${ }^{11}$ :

$$
\delta=\frac{1}{n_{p c=1}} \sum_{i}\left(h w a g e_{i, p c=1}^{c u r}-h w a g e_{i}^{\text {prev }}\right)-\sum_{j} w(i, j)\left(h w a g e_{j, p c=0}^{\text {cur }}-h w a g e_{j}^{\text {prev }}\right)
$$

where $\delta$ is the causal effect of personal contacts, which is equivalent to the coefficient $\beta_{2}$ of personal contacts in the fixed-effects wage regression; the superscripts cur and prev refer to the current and previous job; the sub-script $\mathrm{i}$ denotes individuals who used contacts for their current job; $\mathrm{j}$ denotes those individuals who did not use contacts for their current job regardless of the method used in their previous job $^{12} ; \mathrm{pc}=1$ if the current job was found via personal contacts and $\mathrm{pc}=0$ otherwise; $n_{p c=1}$ is

\footnotetext{
${ }^{10}$ There is an exception to this general statistical relationship if the assumption of temporal homogeneity does not hold in a specific empirical application, i.e., the assumption that net of all covariates, the changes in the dependent variable over time differ between job-finding methods. Then, method keepers contribute if time dummies are included (Brüderl and Ludwig 2015). In the empirical analyses of Mouw (2003) and McDonald (2015). temporal homogeneity seems to hold as indicated by the fact that excluding time dummies does not substantially change the estimates. Therefore, we can ignore this special case.

${ }^{11}$ We focus on the average treatment effect on the treated, because this measure best corresponds to the coefficient from a fixed effects regression (Brüderl and Ludwig 2015) here.

${ }^{12}$ Restricting the analysis to specific pc values in the previous job is possible and recommended by An and Winship (2017). Because imposing this restriction can reduce the number of cases available for matching, we chose to include the previous pc value as a predictor in the propensity score equation. Thus, even at the
} 
the number of individuals who used personal contacts to obtain their current job, $h w a g e_{i, p c=1}^{c u r}$ denotes the outcome variable hourly wages for contact users in the current job; and $h w a g e_{i}^{\text {prev }}$ denotes the hourly wages for the same individuals in the job preceding the current job. The parameters $h w a g e_{j, p c=0}^{c u r}$ and $h w a g e_{j}^{p r e v}$ are the respective values for those individuals who did not use personal contacts to obtain the current job. The value of $h w a g e_{i, p c=1}^{c u r}-h w a g e_{i}^{\text {prev }}$ is positive if wages are higher in the current job and negative if they are lower. Compared with fixed-effects regressions, the wage difference can be calculated for the method changers and method keepers. This fact is reflected in the notation, where the previous wages are not subscripted to indicate the job-finding method.

Moreover, $w(i, j)$ is the weight given to observation $j$ if matched to observation $i$. Different versions of the matching estimators can be built depending on the choice of $w(i, j)$. The most intuitive matching algorithm is the single nearest-neighbor matching (SNNM). In SNNM without replacement, observation $j$ is chosen as a match for observation $i$ if it is closest to $i$ in terms of the absolute distance in their propensity scores $\left|P\left(x_{i}\right)-P\left(x_{j}\right)\right|$. Then, the SNNM weighs the outcome of observation $j$, whose propensity score is closest to that of observation $i$, with $w(i, j)=1$, and it weighs all other control observations with $w(i, j)=0$ and then calculates the causal effect. In multiple nearest-neighbor matching (MNNM), a weighted average of two or more observations $j$ is built for each treatment individual. Often, a maximum acceptable distance (caliper) is set to avoid matches in which $P\left(\boldsymbol{x}_{\boldsymbol{j}}\right)$ is extremely distant from $P\left(\boldsymbol{x}_{\boldsymbol{i}}\right)$ even though it is the nearest neighbor. Observations for which no suitable matching partner is found and observations that are not good matches for any other observation (the technical term is "off support") are eliminated from the analysis.

The propensity score is defined as the probability of being in the treatment group, conditional on all confounding variables. However, the propensity score is generally unknown and must be estimated using a logistic regression (or a similar binary outcome model):

$\hat{p}\left(\boldsymbol{x}_{\boldsymbol{i}}\right)=\hat{p}\left(p c_{i}=1 \mid \boldsymbol{x}_{\boldsymbol{i}}\right)=\left(1+\exp \left(-\left(\boldsymbol{x}_{\boldsymbol{i}} \widehat{\beta}\right)\right)\right)^{-1}$

For the matching estimator to be unbiased, conditional independence must hold, i.e., vector $\mathbf{x}$ must contain all variables simultaneously influencing the treatment probability and the outcome of interest. Following An and Winship (2017), we include not only the current values of the covariates but also the covariate values from the previous job in the propensity score equation. Because the independent variables are not differenced, we can also keep the time-constant variables as controls in the propensity score equation. Similar to fixed-effects regressions, however, considering the differences between the current and previous wages also removes unobserved time-constant heterogeneity.

individual level, cases with $p c^{\text {prev }}=1$ are matched to cases with $p c^{\text {prev }}=0$. On average, the proportion of $p c^{\text {prev }}=1$ in both groups is balanced (see balancing tables). 
Because the matching estimator is essentially a weighted difference in means, it is non-parametric in the sense that it does not require functional form assumptions regarding the relationship of independent variables and outcomes. Furthermore, there is no need to assume a normal distribution for the outcome variable. Because of this, there is no need to take the logarithm of wages as the dependent variable. 


\section{Appendix B}

\section{Replication of the Mouw (2003) analysis}

In Table B1, only the logistic regression of the full sample contains a coefficient for the lagged personal contact variable (Model 1) because the two sub-samples are restricted such that the value of the lag perfectly predicts the value of the personal contact variable ${ }^{13}$. Third, none of the logistic regressions contains coefficients for employed and unemployed non-searches because no information was collected regarding the job-finding method from the survey respondents who reported being nonsearchers, which is partially obscured in Mouw's (2003) operationalization. Based on the second and third aspects, variation in the variables "lag employed non-searcher" and "lag unemployed nonsearcher" can only exist in the full sample. For the restricted sub-samples, no coefficients are estimated, and the respective individuals are eliminated from the sample. ${ }^{14}$

Table B1: Logistic regressions to estimate the propensity scores using the Mouw (2003) sample

\begin{tabular}{|c|c|c|c|}
\hline \multicolumn{4}{|c|}{ Dependent variable: personal contacts vs formal search } \\
\hline & Full sample & Method changers & Method keepers \\
\hline & Model 1 & Model 2 & Model 3 \\
\hline \multicolumn{4}{|l|}{ Covariates current job } \\
\hline Unemployed search $^{\mathrm{a}}$ & $\begin{array}{c}-0.042 * * \\
(0.015)\end{array}$ & $\begin{array}{l}-0.113 * * \\
(0.039)\end{array}$ & $\begin{array}{c}0.001 \\
(0.012)\end{array}$ \\
\hline Employed non-search & - & - & - \\
\hline Unemployed non-search & - & - & - \\
\hline Tenure & $\begin{array}{c}0.017 \\
(0.015)\end{array}$ & $\begin{array}{c}0.044 \\
(0.031)\end{array}$ & $\begin{array}{c}0.018 \\
(0.030)\end{array}$ \\
\hline$(\text { Tenure })^{2}$ & $\begin{array}{l}-0.003 \\
(0.002)\end{array}$ & $\begin{array}{l}-0.002 \# \\
(0.001)\end{array}$ & $\begin{array}{l}-0.013 \\
(0.013)\end{array}$ \\
\hline Experience & $\begin{array}{l}-0.011 \\
(0.042)\end{array}$ & $\begin{array}{l}-0.125 \\
(0.108)\end{array}$ & $\begin{array}{c}0.035 \\
(0.029)\end{array}$ \\
\hline$(\text { Experience })^{2}$ & $\begin{array}{c}0.001 \\
(0.002)\end{array}$ & $\begin{array}{c}0.006 \\
(0.004)\end{array}$ & $\begin{array}{l}-0.001 \\
(0.001)\end{array}$ \\
\hline \multicolumn{4}{|l|}{ Covariates previous job } \\
\hline $\begin{array}{l}\text { Lag "Used solely contact to } \\
\text { find the job" }\end{array}$ & $\begin{array}{c}0.028 \\
(0.019)\end{array}$ & & \\
\hline Lag "Unemployed search"c & $\begin{array}{c}0.010 \\
(0.016)\end{array}$ & $\begin{array}{c}0.043 \\
(0.041)\end{array}$ & $\begin{array}{l}-0.015 \\
(0.013)\end{array}$ \\
\hline Lag "Employed non-search"c & $\begin{array}{c}0.038 \\
(0.025)\end{array}$ & & \\
\hline Lag "Unemployed non-search"c & $\begin{array}{l}0.058^{*} \\
(0.028)\end{array}$ & & \\
\hline Lag "Tenure" & $\begin{array}{c}0.006 \\
(0.006)\end{array}$ & $\begin{array}{l}-0.023 \\
(0.017)\end{array}$ & $\begin{array}{l}0.011^{*} \\
(0.005)\end{array}$ \\
\hline Lag “(Tenure) $)^{2 ،}$ & $\begin{array}{l}-0.000 \\
(0.001)\end{array}$ & $\begin{array}{c}0.001 \\
(0.001)\end{array}$ & $\begin{array}{l}-0.001 \\
(0.000)\end{array}$ \\
\hline Lag "Experience“" & $\begin{array}{c}0.019 \\
(0.043)\end{array}$ & $\begin{array}{c}0.136 \\
(0.106)\end{array}$ & $\begin{array}{l}-0.033 \\
(0.029)\end{array}$ \\
\hline Lag “(Experience $)^{2 ، ،}$ & $\begin{array}{l}-0.001 \\
(0.002)\end{array}$ & $\begin{array}{l}-0.007 \\
(0.004)\end{array}$ & $\begin{array}{c}0.001 \\
(0.001)\end{array}$ \\
\hline
\end{tabular}

\footnotetext{
${ }^{13}$ For the method changers, the lagged variable is always 0 if the personal contact variable is 1 and vice versa. For the method keepers, the lagged variable is always the same variable as the personal contact variable.

${ }^{14}$ Thus, the observations of the two sub-samples do not add to the full sample.
} 
Time constant control variables

1998

\begin{tabular}{ccc}
-0.007 & 0.027 & -0.004 \\
$(0.015)$ & $(0.039)$ & $(0.013)$ \\
-0.020 & -0.006 & -0.015 \\
$(0.015)$ & $(0.038)$ & $(0.012)$ \\
-0.014 & -0.057 & 0.023 \\
$(0.020)$ & $(0.056)$ & $(0.016)$ \\
$0.039 * *$ & -0.037 & $0.040^{* *}$ \\
$(0.016)$ & $(0.041)$ & $(0.014)$ \\
$-0.017 * * *$ & 0.001 & $-0.012^{* * *}$ \\
$(0.003)$ & $(0.009)$ & $(0.003)$ \\
\hline & & \\
3036 & 720 & 1654 \\
2509 & 665 & 1424 \\
558 & 312 & 108 \\
0.020 & 0.022 & 0.050 \\
\hline
\end{tabular}

Sex

(female)

Race

(Hispanic) $^{\mathrm{b}}$

Race

(black) $^{\mathrm{b}}$

Years of

education

control variables

Model summary

Observations

Persons

Contact users

R-squared

Marginal effects; standard errors in parentheses

$* * * \mathrm{p}<0.001, * * \mathrm{p}<0.01, * \mathrm{p}<0.05, \# \mathrm{p}<0.10$

${ }^{a}$ Reference category is "Employed search"

b Reference category is "Non-black, non-Hispanic"

c Reference category is Lag "Employed search"

Table B2 presents the so-called balancing tables in which we report the amount of balance achieved in all three samples. According to the standardized bias, balancing was successful in all three samples and is always below 5 percent as recommended by Caliendo and Kopining (2008). In fact, the least balanced variable is the variable "years of education" in the sample of method keepers, where the standardized bias is 4.4 percent.

Table B2: Balancing tables using the Mouw (2003) sample

\begin{tabular}{|c|c|c|c|c|c|c|c|c|c|}
\hline & \multicolumn{3}{|c|}{ Full sample } & \multicolumn{3}{|c|}{ Method changers } & \multicolumn{3}{|c|}{ Method keepers } \\
\hline & Contact & Formal & & Contact & Formal & & Contact & Formal & \\
\hline & Mean & Mean & $\%$ bias & Mean & Mean & $\%$ bias & Mean & Mean & $\%$ bias \\
\hline Unemployed search & 0.510 & 0.519 & -1.8 & 0.497 & 0.497 & -0.1 & 0.570 & 0.573 & -0.7 \\
\hline Employed search & 0.490 & 0.481 & 1.8 & 0.503 & 0.503 & 0.1 & 0.430 & 0.427 & 0.7 \\
\hline Employed non-search & n.a. & n.a. & n.a. & n.a. & n.a. & n.a. & n.a. & n.a. & n.a. \\
\hline $\begin{array}{l}\text { Unemployed non - } \\
\text { search }\end{array}$ & n.a. & n.a. & n.a. & n.a. & n.a. & n.a. & n.a. & n.a. & n.a. \\
\hline Tenure & 0.870 & 0.869 & 0.1 & 0.859 & 0.836 & 1.9 & 0.802 & 0.787 & 2.1 \\
\hline$(\text { Tenure })^{2}$ & 1.265 & 1.223 & 0.3 & 1.272 & 1.073 & 0.7 & 0.978 & 0.947 & 0.6 \\
\hline Experience & 11.901 & 11.85 & 1.3 & 11.723 & 11.714 & 0.2 & 12.013 & 11.901 & 2.8 \\
\hline$(\text { Experience })^{2}$ & 157.7 & 156.91 & 0.9 & 153.54 & 153.35 & 0.2 & 159.9 & 156.95 & 3.3 \\
\hline $\begin{array}{l}\text { Lag "Personal } \\
\text { contact" }\end{array}$ & 0.194 & 0.194 & 0.0 & & & & & & \\
\hline $\begin{array}{l}\text { Lag "Unemployed } \\
\text { search" }\end{array}$ & 0.476 & 0.476 & -0.1 & 0.647 & 0.643 & 0.9 & 0.561 & 0.564 & -0.7 \\
\hline $\begin{array}{l}\text { Lag "Employed } \\
\text { search" }\end{array}$ & 0.278 & 0.278 & -0.0 & 0.353 & 0.357 & -0.9 & 0.439 & 0.436 & 0.7 \\
\hline $\begin{array}{l}\text { Lag "Employed } \\
\text { non-search" }\end{array}$ & 0.135 & 0.134 & 0.1 & n.a. & n.a. & n.a. & n.a. & n.a. & n.a. \\
\hline $\begin{array}{l}\text { Lag "Unemployed } \\
\text { non-search" }\end{array}$ & 0.111 & 0.111 & 0.0 & n.a. & n.a. & n.a. & n.a. & n.a. & n.a. \\
\hline
\end{tabular}




\begin{tabular}{lccccccccc} 
Lag "Tenure“ & 2.336 & 2.343 & -0.2 & 2.116 & 2.059 & 1.8 & 2.762 & 2.723 & 1.2 \\
Lag "(Tenure)" & 14.899 & 15.195 & -0.8 & 12.911 & 11.95 & 2.5 & 19.02 & 18.738 & 0.7 \\
Lag "Experience" & 11.432 & 11.38 & 1.3 & 11.233 & 11.216 & 0.4 & 11.51 & 11.411 & 2.5 \\
Lag "(Experience)"، & 146.2 & 145.41 & 0.9 & 141.68 & 141.28 & 0.5 & 147.64 & 145.45 & 2.5 \\
1996 & 0.512 & 0.507 & 1.0 & 0.474 & 0.478 & -0.9 & 0.523 & 0.522 & 0.3 \\
1998 & 0.488 & 0.493 & -1.0 & 0.526 & 0.521 & 0.9 & 0.477 & 0.478 & -0.3 \\
Sex (female) & 1.452 & 1.457 & -0.9 & 1.435 & 1.433 & 0.4 & 1.421 & 1.409 & 2.4 \\
Race (Hispanic) & 0.162 & 0.158 & 0.9 & 0.131 & 0.128 & 0.9 & 0.206 & 0.192 & 3.4 \\
Race(black) & 0.399 & 0.400 & -0.3 & 0.425 & 0.430 & -1.1 & 0.439 & 0.455 & -3.3 \\
Race (non-black, & 0.440 & 0.442 & -0.4 & 0.444 & 0.442 & 0.5 & 0.355 & 0.352 & 0.5 \\
non-Hispanic) & & & & & & & & & \\
Years of education & 12.443 & 12.427 & 0.7 & 12.5 & 12.461 & 1.8 & 12.243 & 12.338 & -4.4 \\
\hline
\end{tabular}

\section{Replication of the McDonald (2015) analysis}

Table B3: Logistic regressions to estimate the propensity scores using the McDonald (2015) sample

\begin{tabular}{|c|c|c|}
\hline & Contact vs. formal & Non-search vs. formal \\
\hline & Model 1 & Model 2 \\
\hline \multicolumn{3}{|l|}{ Covariates current job } \\
\hline \multirow[t]{2}{*}{ Employed when hired } & $0.033^{*}$ & $0.224 * * *$ \\
\hline & $(0.015)$ & $(0.014)$ \\
\hline \multirow[t]{2}{*}{ Experience } & $-0.050 * *$ & -0.008 \\
\hline & $(0.016)$ & $(0.016)$ \\
\hline \multirow{2}{*}{$(\text { Experience })^{2}$} & $0.002 * *$ & 0.000 \\
\hline & $(0.001)$ & $(0.001)$ \\
\hline \multirow[t]{2}{*}{ Job number } & -0.003 & -0.013 \\
\hline & $(0.016)$ & $(0.016)$ \\
\hline \multirow[t]{2}{*}{ Inverse Mill's ratio } & $-0.173 \#$ & $0.332 * * *$ \\
\hline & $(0.099)$ & $(0.092)$ \\
\hline \multicolumn{3}{|l|}{ Covariates previous job } \\
\hline \multirow[t]{2}{*}{ Lag "Used contact to find the job" } & $0.062 * * *$ & $0.030 \#$ \\
\hline & $(0.017)$ & $(0.018)$ \\
\hline \multirow[t]{2}{*}{ Lag "Non-search"” } & $0.049 * *$ & $0.142 * * *$ \\
\hline & $(0.018)$ & $(0.016)$ \\
\hline \multirow[t]{2}{*}{ Lag "Employed when hired" } & -0.019 & $-0.028 \#$ \\
\hline & $(0.015)$ & $(0.015)$ \\
\hline \multirow[t]{2}{*}{ Lag "Experience" } & $0.048 * *$ & 0.020 \\
\hline & $(0.018)$ & $(0.017)$ \\
\hline \multirow[t]{2}{*}{ Lag "(Experience) $)^{2 "}$} & $-0.002 * *$ & -0.001 \\
\hline & $(0.001)$ & $(0.001)$ \\
\hline \multirow[t]{2}{*}{ Lag "Inverse Mill's ratio" } & -0.096 & 0.038 \\
\hline & $(0.099)$ & $(0.093)$ \\
\hline \multicolumn{3}{|l|}{ Time constant control variables } \\
\hline \multirow[t]{2}{*}{1998} & -0.008 & $0.030 \#$ \\
\hline & $(0.018)$ & $(0.018)$ \\
\hline \multirow[t]{2}{*}{2000} & 0.004 & $0.054 * *$ \\
\hline & (0.019) & $(0.019)$ \\
\hline Sex & $-0.033 \#$ & $0.060 * * *$ \\
\hline (female) & $(0.017)$ & $(0.016)$ \\
\hline Race & $0.045^{*}$ & 0.006 \\
\hline
\end{tabular}




\begin{tabular}{lcc} 
(Hispanic) $^{\mathrm{b}}$ & $(0.023)$ & $(0.022)$ \\
Race & $0.073^{* * *}$ & $-0.045^{*}$ \\
(black) $^{\mathrm{b}}$ & $(0.018)$ & $(0.017)$ \\
Years of education & 0.002 & $-0.021^{* * *}$ \\
& $(0.005)$ & $(0.005)$ \\
\hline \hline Model summary & & \\
Observations & 4053 & 4378 \\
Number of caseid & 3050 & 3301 \\
Contact users & 1121 & $/$ \\
R-squared & 0.013 & 0.071 \\
\hline \hline
\end{tabular}

Marginal effects, standard errors in parentheses

$* * * \mathrm{p}<0.001, * * \mathrm{p}<0.01, * \mathrm{p}<0.05, \# \mathrm{p}<0.10$

a Reference category is Lag "Used formal means"

b Reference category is "Non-black, non-Hispanic"

Table B4 ensures that the propensity score matching successfully eliminated all observed differences, which is the case. The worst balanced variable has a standardized bias of only 2 percent.

Table B4: Balancing tables using the McDonald (2015) sample

\begin{tabular}{|c|c|c|c|c|c|c|}
\hline & \multicolumn{3}{|c|}{ Contact vs. formal } & \multicolumn{3}{|c|}{ Non-search vs. formal } \\
\hline & Contact & Formal & & Non-search & Formal & \\
\hline & Mean & Mean & $\%$ bias & Mean & Mean & $\%$ bias \\
\hline Employed when hired & 0.475 & 0.479 & -0.8 & 0.710 & 0.716 & -1.4 \\
\hline Experience & 13 & 13.009 & -0.2 & 13.793 & 13.734 & 1.4 \\
\hline$(\text { Experience })^{2}$ & 190.14 & 190.18 & -0.0 & 208.81 & 207.32 & 1.3 \\
\hline Job number & 1.161 & 1.161 & -0.1 & 1.142 & 1.148 & -1.5 \\
\hline Inverse Mill's ratio & 0.392 & 0.392 & -0.2 & 0.424 & 0.424 & 0.1 \\
\hline Lag "Personal contact" & 0.273 & 0.270 & 0.8 & 0.196 & 0.196 & 0.2 \\
\hline Lag "Non-search" & 0.216 & 0.220 & -0.9 & 0.326 & 0.318 & 1.9 \\
\hline $\begin{array}{l}\text { Lag "Employed when } \\
\text { hired" }\end{array}$ & 0.423 & 0.421 & 0.4 & 0.494 & 0.485 & 1.7 \\
\hline Lag “Experience” & 10.996 & 10.99 & 0.1 & 11.614 & 11.566 & 1.2 \\
\hline Lag “(Experience) $)^{2 »}$ & 137.37 & 137.14 & 0.3 & 150.05 & 149.2 & 1.0 \\
\hline Lag "Inverse Mill's ratio" & 0.383 & 0.383 & -0.3 & 0.407 & 0.407 & -0.1 \\
\hline 1996 & 0.3 & 0.303 & -0.6 & 0.266 & 0.266 & 0.2 \\
\hline 1998 & 0.340 & 0.340 & 0.0 & 0.351 & 0.345 & 1.2 \\
\hline 2000 & 0.360 & 0.357 & 0.6 & 0.382 & 0.389 & -1.4 \\
\hline Sex (female) & 1.465 & 1.462 & 0.7 & 1.492 & 1.505 & -2.6 \\
\hline Race (Hispanic) & 0.356 & 0.358 & -0.4 & 0.417 & 0.415 & 0.5 \\
\hline Race (black) & 0.45 & 0.450 & 0.0 & 0.334 & 0.342 & -1.6 \\
\hline $\begin{array}{l}\text { Race (non-black, non- } \\
\text { Hispanic) }\end{array}$ & 0.194 & 0.192 & 0.5 & 0.249 & 0.244 & 1.3 \\
\hline Years of education & 12.753 & 12.76 & -0.3 & 13.034 & 13.082 & -2.0 \\
\hline
\end{tabular}


Table B5: Effects of changes of Mouw's (2003) and McDonald's (2015) wage regressions

\begin{tabular}{|c|c|c|c|c|c|c|c|}
\hline & $\begin{array}{l}\text { Mouw's } \\
\text { model }\end{array}$ & Step 1 & Step 2 & Step 3 & Step 4 & $\begin{array}{l}\text { McDonald's } \\
\text { model }\end{array}$ & $\begin{array}{l}\text { Alternative } \\
\text { model }\end{array}$ \\
\hline Used contact to find the job ${ }^{\mathrm{a}}$ & $\begin{array}{l}0.024 \\
(0.016)\end{array}$ & $\begin{array}{l}0.027 \# \\
(0.014)\end{array}$ & $\begin{array}{l}0.021 \\
(0.015)\end{array}$ & $\begin{array}{l}0.022 \# \\
(0.012)\end{array}$ & $\begin{array}{l}0.019 * \\
(0.010)\end{array}$ & $\begin{array}{l}0.019 * \\
(0.009)\end{array}$ & $\begin{array}{l}0.019 \# \\
(0.011)\end{array}$ \\
\hline Non-search ${ }^{\mathrm{a}}$ & & & $\begin{array}{l}0.043^{* *} \\
(0.015)\end{array}$ & $\begin{array}{l}0.030^{*} \\
(0.012)\end{array}$ & $\begin{array}{l}0.025^{* *} \\
(0.009)\end{array}$ & $\begin{array}{l}0.023^{*} \\
(0.009)\end{array}$ & $\begin{array}{l}0.026^{*} \\
(0.011)\end{array}$ \\
\hline Unemployed search ${ }^{\mathrm{b}}$ & $\begin{array}{l}-0.075 * * * \\
(0.013)\end{array}$ & $\begin{array}{l}- \\
0.075^{* * * *} \\
(0.013)\end{array}$ & & & & & \\
\hline Employed non-search ${ }^{\mathrm{b}}$ & $\begin{array}{l}0.042 * \\
(0.017)\end{array}$ & $\begin{array}{l}0.044 \\
(0.017)\end{array}$ & & & & & \\
\hline Unemployed non-search ${ }^{\mathrm{b}}$ & $\begin{array}{l}-0.031 \\
(0.022)\end{array}$ & $\begin{array}{l}-0.029 \\
(0.022)\end{array}$ & & & & & \\
\hline Employed when hired & & & $\begin{array}{l}0.074 * * * \\
(0.013)\end{array}$ & $\begin{array}{l}0.084 * * * \\
(0.011)\end{array}$ & $\begin{array}{l}0.072 * * * \\
(0.008)\end{array}$ & $\begin{array}{l}0.069 * * * \\
(0.008)\end{array}$ & $\begin{array}{l}0.076 * * * \\
(0.010)\end{array}$ \\
\hline $\begin{array}{l}\text { Tenure } \\
(\text { Tenure })^{2}\end{array}$ & $\begin{array}{l}0.031 * * * \\
(0.006) \\
-0.001 * * \\
(0.000)\end{array}$ & $\begin{array}{l}0.031 * * * \\
(0.006) \\
-0.001 * * \\
(0.000)\end{array}$ & & & & & \\
\hline Experience & $\begin{array}{l}0.037 \\
(0.035)\end{array}$ & $\begin{array}{l}0.037 \\
(0.035)\end{array}$ & $\begin{array}{l}0.008 \\
(0.015)\end{array}$ & $\begin{array}{l}0.028 * * \\
(0.010)\end{array}$ & $\begin{array}{l}0.021 * * \\
(0.008)\end{array}$ & $\begin{array}{l}0.023 * * \\
(0.008)\end{array}$ & $\begin{array}{l}0.025^{*} \\
(0.010)\end{array}$ \\
\hline$(\text { Experience })^{2}$ & $\begin{array}{l}0.000 \\
(0.001)\end{array}$ & $\begin{array}{l}-0.000 \\
(0.001)\end{array}$ & $\begin{array}{l}0.000 \\
(0.001)\end{array}$ & $\begin{array}{l}0.000 \\
(0.000)\end{array}$ & $\begin{array}{l}0.000 \\
(0.000)\end{array}$ & $\begin{array}{l}0.000 \\
(0.000)\end{array}$ & $\begin{array}{l}0.000 \\
(0.000)\end{array}$ \\
\hline 1996 & $\begin{array}{l}0.103 * * * \\
(0.015)\end{array}$ & $\begin{array}{l}0.103 * * * \\
(0.015)\end{array}$ & $\begin{array}{l}0.093 * * * \\
(0.015)\end{array}$ & $\begin{array}{l}0.065 * * * \\
(0.013)\end{array}$ & $\begin{array}{l}0.053 * * * \\
(0.010)\end{array}$ & $\begin{array}{l}0.048 * * * \\
(0.010)\end{array}$ & $\begin{array}{l}0.064 * * * \\
(0.012)\end{array}$ \\
\hline 1998 & $\begin{array}{l}0.180 * * * \\
(0.015)\end{array}$ & $\begin{array}{l}0.181 * * * \\
(0.015)\end{array}$ & $\begin{array}{l}0.125 * * * \\
(0.022)\end{array}$ & $\begin{array}{l}0.072 * * * \\
(0.018)\end{array}$ & $\begin{array}{l}0.072 * * * \\
(0.014)\end{array}$ & $\begin{array}{l}0.061 * * * \\
(0.014)\end{array}$ & $\begin{array}{l}0.065 * * * \\
(0.018)\end{array}$ \\
\hline 2000 & & & & $\begin{array}{l}0.128 * * * \\
(0.026)\end{array}$ & $\begin{array}{l}0.136 * * * \\
(0.019)\end{array}$ & $\begin{array}{l}0.122 * * * \\
(0.019)\end{array}$ & $\begin{array}{l}0.123 * * * \\
(0.026)\end{array}$ \\
\hline Job number & & & & & $\begin{array}{l}-0.06 * * * \\
(0.005)\end{array}$ & $\begin{array}{l}-0.057 * * * \\
(0.005)\end{array}$ & \\
\hline Inverse Mill's ratio & & & & & & $\begin{array}{l}0.740 * * * \\
(0.058)\end{array}$ & $\begin{array}{l}0.698 * * * \\
(0.080)\end{array}$ \\
\hline Constant & $\begin{array}{l}1.746 * * * \\
(0.247)\end{array}$ & $\begin{array}{l}1.748 * * * \\
(0.247)\end{array}$ & $\begin{array}{l}2.160 * * * \\
(0.111)\end{array}$ & $\begin{array}{l}1.957 * * * \\
0.076\end{array}$ & $\begin{array}{l}2.095 * * * \\
0.059\end{array}$ & $\begin{array}{l}1.800 * * * \\
(0.062)\end{array}$ & $\begin{array}{l}1.688 * * * \\
(0.083)\end{array}$ \\
\hline Model characteristics & & & & & & & \\
\hline Corrected Coding & no & yes & yes & yes & yes & yes & yes \\
\hline $\begin{array}{l}\text { Entry wage as dependent } \\
\text { variable }\end{array}$ & no & no & yes & yes & yes & yes & yes \\
\hline Wave 2000 included & no & no & no & yes & yes & yes & yes \\
\hline Side jobs included & no & no & no & no & yes & yes & yes \\
\hline Mill's Ratio included & no & no & no & no & no & yes & yes \\
\hline Person fixed effects & yes & yes & yes & yes & yes & yes & yes \\
\hline Person-job type fixed effects & no & no & no & no & no & no & yes \\
\hline Model Summary & & & & & & & \\
\hline Observations & 7400 & 7400 & 7650 & 9.471 & 13570 & 13570 & 13570 \\
\hline Number of caseid & 3277 & 3277 & 4535 & 4.702 & 4817 & 4817 & 8071 \\
\hline Contact users & 1106 & 1503 & 1163 & 2043 & 2861 & 2861 & 2861 \\
\hline R-squared & 0.092 & 0.092 & 0.078 & 0.114 & 0.086 & 0.103 & 0.116 \\
\hline
\end{tabular}

